\title{
Transcriptomic profiles of Japanese medaka (Oryzias latipes) in response to alkalinity stress
}

\author{
Z.L. Yao ${ }^{1,2}$, H. Wang ${ }^{2}$, L. Chen ${ }^{1}$, K. Zhou ${ }^{2}$, C.Q. Ying ${ }^{2}$ and Q.F. Lai ${ }^{2}$ \\ ${ }^{1}$ State Key Laboratory of Pollution Control and Resource Reuse, \\ College of Environmental Science and Engineering, Tongji University, \\ Shanghai, China \\ ${ }^{2}$ Key Laboratory of East China Sea and Oceanic Fishery Resources Exploitation, \\ Ministry of Agriculture of China, East China Sea Fisheries Research Institute, \\ Chinese Academy of Fisheries Sciences, Shanghai, China
}

Corresponding author: Q.F. Lai

E-mail: qifanglai@163.com / zlyao@126.com

Genet. Mol. Res. 11 (3): 2200-2246 (2012)

Received January 23, 2012

Accepted May 25, 2012

Published June 15, 2012

DOI http://dx.doi.org/10.4238/2012.June.15.2

\begin{abstract}
Oryzias latipes (Adrianichthyidae), known as Japanese medaka or Japanese killifish, is a small 2-4 cm long fish common in rice paddies in coastal Southeast Asia and is also a popular aquarium fish. It has been widely used as a research model because of its small size and because it is very easy to rear. Alkalinity stress is considered to be one of the major stressors on fish in saline-alkaline water. As very little is known about molecular genetic responses of aquatic organisms to alkalinity stress, we examined genome-wide gene expression profiles of Japanese medaka in response to carbonate alkalinity stress. Adult fish were exposed to freshwater and high carbonate alkaline water in the laboratory. We designed a microarray containing 26,429 genes for measuring gene expression change in the gills of the fish exposed to high carbonate alkalinity stress. Among these genes, 512 were up-regulated and 501 were downregulated in the gills. These differentially expressed genes can be divided into gene groups using gene ontology, including biological processes, cellular components and molecular function. These gene
\end{abstract}


groups are related to acid-base and ion regulation, cellular stress response, metabolism, immune response, and reproduction processes. Biological pathways including amino sugar and nucleotide sugar metabolism, porphyrin and chlorophyll metabolism, metabolism of xenobiotics by cytochrome P450, drug metabolism, aminoacyl-tRNA biosynthesis, glycine, serine and threonine metabolism, ascorbate and aldarate metabolism, pentose and glucuronate interconversions, glutathione metabolism, and fructose and mannose metabolism were significantly up-regulated. Alkalinity stress stimulates the energy and ion regulation pathways, and it also slows down the pathways related to the immune system and reproduction.

Key words: Oryzias latipes; Alkalinity stress; Transcriptomics; Microarray

\section{INTRODUCTION}

Carbonate alkalinity stress is considered to be one of the major stressors on fishes in saline-alkali water. Carbonate alkalinity stress on fishes is related to acid-base regulation (Perry and Gilmour, 2006) and excretion of carbon dioxide (Randall and Tsui, 2006), and is dependent on ionic regulation and osmoregulation in fishes as well (Goss et al., 1994). Major problems for fishes living in alkaline water are that high $\mathrm{pH}$ may inhibit ammonia excretion, and increase $\mathrm{CO}_{2}$ excretion (Parra and Baldisserotto, 2007). A number of studies have reported that high carbonate alkalinity induces mixed respiratory and metabolic alkalosis in freshwater fish (Wilkie and Wood, 1996).

In an extreme natural alkaline environment, some fishes have developed special strategies to adapt to high alkalinity and $\mathrm{pH}$. For example, Lake Magadi tilapia (Tilapia grahami) excretes all of its waste nitrogen as urea (Wilkie and Wood, 1996); Lahontan cutthroat trout (Oncorhynchus clarki henshawi) is able to survive in alkaline water because of its ability to reduce ammonia production and possibly stimulate $\mathrm{Cl}^{-} / \mathrm{HCO}_{3}^{-}$exchange in the gills by branchial cell chloride proliferation (Wilkie and Wood, 1996), and the scale-less carp (Gymnocypris przewalskii) reduces $\mathrm{NH}_{3}$ production, and accumulates this metabolite in the muscle to attenuate levels in other tissues, and possibly incorporates $\mathrm{NH}_{3}$ into amino acids (Wang et al., 2003).

In order to acclimate to environments with varied salinities, diverse ion compositions, and varied $\mathrm{pH}$, fishes must have highly efficient ion and osmoregulatory mechanisms (Hwang and Lee, 2007). Ion transportation is an essential function in many animal tissues to modulate ion flux in response to changes of internal and external environments (Scott et al., 2004). The gill is the major site of acid-base regulation in most fish species (Claiborne et al., 2002). Acid-base transfer across the gill is dominated by carbon dioxide (Randall and Tsui, 2006). It is likely that long-term regulation of acid-base balance in fish exposed to alkaline water is dependant upon the independent modulation of $\mathrm{Na}^{+}$and $\mathrm{Cl}^{-}$movements across the gill epithelium (Wilkie and Wood, 1996).

Fishes need complex changes in physiological and gene regulatory networks, and numerous cellular pathways to acclimate to environmental stressors (Fiol and Kültz, 2007; 
Evans, 2010). For osmotic stress, as an example, the osmosensory signal transduction network in fishes includes calcium, mitogen-activated protein kinase, 14-3-3 and macromolecular damage-activated signaling pathways (Fiol and Kültz, 2007). In additional to intracellular signaling mechanisms, the response to osmotic stress in euryhaline fish is harmonized via hormone and paracrine factor-mediated extracellular signaling (Fiol and Kültz, 2007).

Medaka (Oryzias latipes) is a model vertebrate commonly used in studies on developmental and evolutionary biology. The genome size of medaka is about one-half that of zebrafish, another common model animal (Takeda and Shimada, 2010). Moreover, considerable sequence information of medaka is available for molecular study (Kasahara et al., 2007). In addition, medaka is adaptable to seawater at most stages examined (Inoue and Takei, 2002), making it a good model for studying mechanisms of acclimation to salt water.

DNA microarray technology has proven to be a powerful tool for the genome-wide assessment of gene transcript levels associated with physiological responses to environmental stressors, such as osmotic stress (Evans, 2010), hypoxia (Zhang et al., 2009) and heat stress (Lockwood et al., 2010). This technology simultaneously detects the expression of many thousands of gene transcripts in response to variations resulting from differences in environmental stressors. Thus, microarrays allow assembly of gene expression in tissues under given conditions (Gibson, 2008). Medaka microarray has been applied to the study of environmental toxicity (Yum et al., 2010) and temperature change (Hirayama et al., 2005). However, this technology has not been utilized in alkalinity stress-related research. The use of microarrays to enhance our understanding of the responses of aquatic animals to alkalinity stress on the molecular level is incipient.

Modulation of expression and activity of some proteins involved in $\mathrm{pH}$ or acid-base acclimation of some fish species have been identified, including carbonic anhydrase, $\mathrm{Na}^{+}$, $\mathrm{K}^{+}$-ATPase, V-H-ATPase. However, molecular genetic response to alkalinity stress is highly complex, and overlaps with responses to other stresses, making it difficult to identify alkalinity-specific responses using traditional single gene or low throughput approaches. Therefore, we determined genome-wide gene expression profiles to better understand how carbonate alkalinity stress influences global gene expression in medaka in the present study.

\section{MATERIAL AND METHODS}

\section{Experimental fish}

Laboratory-raised medaka fish were used for this study. Fish (body weight and total length were $910 \pm 57 \mathrm{mg}$ and $42 \pm 0.7 \mathrm{~mm}$, respectively, $\mathrm{N}=30$; data reported as means \pm SEM) were maintained in a 50-L glass tank with filtered dechlorinated tap water for at least two weeks. Temperature, dissolved oxygen, $\mathrm{pH}$, ammonia, and nitrite were maintained at $26 \pm$ $1{ }^{\circ} \mathrm{C}, 5.8 \pm 0.8 \mathrm{mg} / \mathrm{L}, 7.5 \pm 0.4,<0.1 \mathrm{mg} / \mathrm{L}$, and $5 \pm 1 \mathrm{mg} / \mathrm{L}$, respectively.

\section{Carbonate alkalinity exposure and tissue sampling}

Carbonate alkalinity solution was prepared using $\mathrm{NaHCO}_{3}$ and $\mathrm{Na}_{2} \mathrm{CO}_{3}$, and dechlorinated filtered tap water, which was maintained in a plastic tank and aerated for 24 $\mathrm{h}$ before use. The carbonate alkalinity was determined every day throughout the exposure 
period with acidimetric titrations, and expressed as $\mathrm{mM}$. Exposure tests were conducted in 15-L flow-through tanks $(14 \mathrm{~cm} \times 10 \mathrm{~cm} \times 8.5 \mathrm{~cm})$ containing about $10 \mathrm{~L}$ of the test solution, each with 15 adult fishes. The $90 \%$ solution in the test tanks was changed daily. The fish were exposed to freshwater (FW) (carbonate alkalinity $=1.5 \pm 0.1 \mathrm{mM}, \mathrm{pH}=8.4 \pm 0.2$, $\mathrm{pCO}_{2}=4 \pm 1$ torr) and alkaline water (AW) (carbonate alkalinity $=30.4 \pm 0.4 \mathrm{mM}, \mathrm{pH}=$ $9.2 \pm 0.0, \mathrm{pCO}_{2}=2 \pm 1$ torr) for $96 \mathrm{~h}$, each treatment had three tanks, each with $15 \mathrm{fish}$. The alkalinity concentration $(30.4 \pm 0.4 \mathrm{mM})$ was tested because our previous study indicates that development of medaka was greatly affected at this alkalinity concentration (Yao et al., 2010). Photoperiod was 16-h light:8-h dark. Water temperature was controlled at $26^{\circ} \pm 1{ }^{\circ} \mathrm{C}$ with a heater. The fish were not fed during the stress experiment. At the end of exposure, the gills of 3 adult fishes in each tank were sampled, and immediately frozen in liquid nitrogen, then stored at $-80^{\circ} \mathrm{C}$ for gene expression analysis. Altogether, gills of 9 fish in $\mathrm{FW}$ and 9 fish in AW were sampled.

\section{Oxygen consumption and plasma chemistry analysis}

Oxygen consumption of medaka exposed to FW and AW for $96 \mathrm{~h}$ was examined. Respirometry trials were conducted in six 0.6-L respirometry chambers ( 3 for FW, 3 for AW) through which water flowed at a constant rate of $75 \mathrm{~mL} / \mathrm{s}$ by an external submersible pump. Water was internally recirculated by an internal pump continually at a flow rate of about $75 \mathrm{~mL} / \mathrm{s}$. The respirometer was submerged in water to keep temperature constant at $26 \pm 1^{\circ} \mathrm{C}$. The fish for the respirometry trials did not feed $24 \mathrm{~h}$ prior to the trials. Fifteen fish were placed in each of the 0.6 -L respiration chambers for $96 \mathrm{~h}$. An oxygen probe (YSI 6562, Yellow Springs, OH, USA), calibrated with air-saturated water and zeroed with sodium bisulfate-saturated water, was inserted in the recirculation tube to monitor oxygen concentration of the bypassing water. The external water stopped flowing through the chambers when internal water oxygen concentration reached the target level. Water oxygen concentration in $\mathrm{mg} / \mathrm{L}$ was recorded every $20 \mathrm{~s}$. Measurements of oxygen consumption lasted 10-30 min, depending on the size of the fish and swimming speed, which was long enough to record a change of $0.5-2.0 \mathrm{mg} \mathrm{O}_{2} / \mathrm{L}$, but without decreasing the dissolved oxygen concentration below $80 \%$ saturation during any measurement. Oxygen consumption was expressed in terms of wet weight of the fish $\left(\mathrm{mg} \mathrm{O}_{2} \cdot \mathrm{kg}^{-1} \cdot \mathrm{h}^{-1}\right)$. After respirometry trials, the fish were anaesthetized by buffered MS-222 (about $0.5 \mathrm{~g} / \mathrm{L}$ ). Afterwards, 10 fish from each chamber were selected, and their tails were cut off and blood was collected with a glass capillary tube (Hirschmann Laborgeraete, Eberstadt, Germany). The blood collected from 10 fish was pooled and centrifuged at $10,000 \mathrm{~g}$ for $30 \mathrm{~s}$. The plasma was collected and used for examining osmolality by a vapor pressure osmomery (Wescor 5520, South Logan, UT, USA). The statistical significance of differences between the two treatments was determined with the Student $t$-test.

\section{RNA extraction}

Total RNA was extracted from 50 100 mg gills from 9 fish in FW and 9 fish in AW using Trizol (Invitrogen, Burlington, ON, Canada) isolation reagent following manufacturer instructions. Total RNA and RNA quality were determined spectrophotometrically (Agilent 
Bioanalyzer 2100, Agilent, Wokingham, Berkshire, UK). Total RNA was treated with RQ1 RNase-free DNase (Promega). Then, two separate pools with equal RNA quantities were prepared: one with nine samples in FW treatment and one with nine samples in AW treatment. RNA samples were stored at $-80^{\circ} \mathrm{C}$ following isolation.

\section{Oligonucleotide microarray fabrication}

Sixty-mer oligonucleotide probes for each DFCI (Dana Farber Cancer Institute), OlGI (O. latipes Gene Index), TCs (Tentative Consensus sequences) were designed by eArray (Agilent, Santa Clara, CA, USA) based on the data from OlGI, updated July 11, 2008 (release 7.0). The total number of TCs was 26,436 (http://compbio.dfci.harvard. edu/cgi-bin/tgi/T_release.pl?gudb=o_latipes; Release 7.0; July 2008). 26,429 60-mer oligonucleotides were successfully designed for 26,429 TCs. Eight microrrays (Agilent $4 \mathrm{x} 44 \mathrm{k}$ design format, Agilent) were produced by in situ oligonucleotide synthesis. The layout of microarray slide consists of 4 duplicated blocks, each block containing a complete set of medaka oligonucleotide probes, positive control, negative control, and empty spot locations.

\section{Microarray hybridization}

Microarray analysis was performed on adult medaka exposed to FW and AW. Sample labeling and hybridization were performed according to the Agilent one-color microarray-based gene expression analysis protocol. Six 44k Agilent test arrays were hybridized with pooled Cyanine-3 (Cy3)-labeled cRNAs gained from the gills of medaka exposed to FW and AW. This microarray design resulted in three arrays for each of the FW and AW treatments. The amplification protocol was started with $2 \mu \mathrm{g}$ RNA. The pooled RNAs from the gills of all fishes of each replicate of the treatments were labeled using the One-Color low RNA input linear amplification kit (Agilent) according to manufacturer instructions, followed by RNAeasy column purification (QIAGEN, Valencia, CA, USA). Dye incorporation and cRNA yield were evaluated with the NanoDrop ND-1000 Spectrophotometer (Wilmington, DE, USA). Then, the labeled cRNA was prepared for fragmentation by adding $11 \mu \mathrm{L} 10 \mathrm{X}$ blocking agent and $2.2 \mu \mathrm{L} 25 \mathrm{X}$ fragmentation buffer, heated at $60^{\circ} \mathrm{C}$ for $30 \mathrm{~min}$, and finally diluted by addition of $55 \mu \mathrm{L} 2 \mathrm{X}$ GE hybridization buffer. A volume of $100 \mu \mathrm{L}$ hybridization solution was then dispensed in the gasket slide and assembled to the microarray slide (each slide containing four arrays). Slides were incubated at $65^{\circ} \mathrm{C}$ in an Agilent hybridization oven for $17 \mathrm{~h}$, subsequently removed from the hybridization chamber, quickly submerged in GE wash buffer 1 to disassemble the slides and then washed in GE Wash Buffer 1 for approximately 1 min followed by one additional wash in pre-warmed $\left(37^{\circ} \mathrm{C}\right) \mathrm{GE}$ Wash Buffer 2 .

After washing, the arrays were scanned on an Agilent G2565BA DNA microarray scanner (Agilent) at a resolution of $5 \mu \mathrm{m}$. The same slide was scanned twice at two different sensitivity levels (XDR Hi 100\% and XDR Lo 10\%). The two generated images were analyzed together and data were extracted and background subtracted using the standard procedures contained in the Agilent feature extraction software 9.1. 


\section{Array data analysis}

Hybridized microarrays were scanned and visualized using an Agilent 2565BA DNA microarray scanner. The scanned images were analyzed with the feature extraction software 9.1 (Agilent). Among these measures the feature extraction software 9.1 flag was used to filter out unreliable probes. Raw data from the Agilent 2565BA were uploaded to GeneSpring GX 10 for quantile normalization. After normalization, differentially expressed genes were identified by unpaired $t$-test. The data addressed here have been deposited in the National Center for Biotechnology Information (NCBI) Gene Expression Omnibus (GEO: www.ncbi. nlm.nih.gov/geo/) and are accessible through the GEO series accession No. GSE27298. Differentially expressed genes identified by the $t$-test were further mined for re-annotation, Gene Ontology (GO) classification and pathway elucidation using the Database for Annotation and Visualization and Integrated Discovery (DAVID http://david.abcc.ncifcrf.gov/) (Dennis Jr. et al., 2003), and Kyoto Encyclopedia of Genes and Genomes (KEGG) (Kanehisa and Goto, 2000) databases.

Differentially expressed genes were subjected to annotation enrichment analysis using the online functional annotation tool DAVID. Danio rerio was used as the background species. Zebrafish gene identifiers were used for this analysis to improve the richness of the output. Significance was calculated by a modified Fisher exact test. From these annotations, GO bar charts were made using 2nd level GO terms based on biological process, molecular function and cellular component. DAVID functional annotation clustering was used to classify the gene functions.

\section{Gene expression analysis based on real-time RT-PCR}

To test whether the changes in gene expression detected with medaka microarray were reproducible by other methods, 10 OlGI sequences were selected for SYBR-based real-time quantitative PCR (qPCR) evaluation. Primers (Table 1) were designed with the Primer 3 program (Rozen and Skaletsky, 2000). Gene expression was assessed using SYBR-based qPCR on LightCycler 1.2 (Roche, Germany). The PCR was carried out with $1 \mu \mathrm{L}$ cDNA, $0.2 \mu \mathrm{L}$ of each primer and $5 \mu \mathrm{L}$ SYBR master mix, in a total volume of $10 \mu \mathrm{L}$. All qPCRs were run for 1 cycle of $10 \mathrm{~s}$ at $95^{\circ} \mathrm{C}$, followed by 40 cycles of $5 \mathrm{~s}$ at $95^{\circ} \mathrm{C}$ and $20 \mathrm{~s}$ at $60^{\circ} \mathrm{C}$. Melting curve analysis was performed following each reaction to confirm that there was only a single product and no primer-dimer artifacts. In addition, representative samples were electrophoresed to verify that only a single product was present. The standard curve of each gene was checked in a linear range with $\beta$-actin as an internal control. Negative control reactions were performed for representative samples using RNA that had not been reversely transcribed to control for the possible presence of genomic DNA contamination. Non-template control reactions were also performed to verify that there was no cDNA, PCR product contamination or primer-dimer amplification in the reactions.

A randomly selected sample was used to develop a standard curve for each primer set, and the results were expressed relative to this arbitrary standard. All samples were run in triplicate. Expression of the different samples was normalized to $\beta$-actin. Relative changes in the expression of candidate genes were calculated by the comparative $\mathrm{C}_{\mathrm{T}}$ method (Schmittgen and Livak, 2008). 


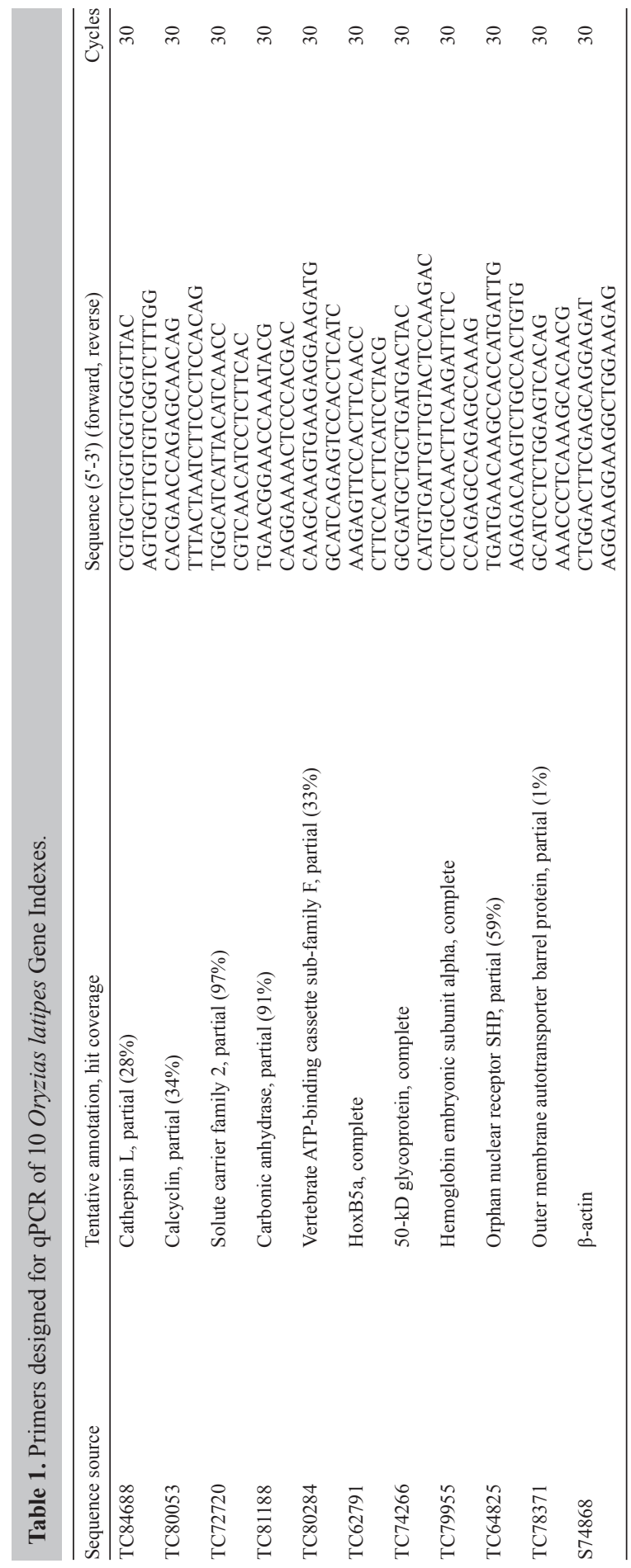




\section{RESULTS AND DISCUSSION}

\section{Oxygen consumption and plasma chemistry}

Exposure to high carbonate alkalinity $(30.4 \mathrm{mM})$ water for $96 \mathrm{~h}$ resulted in a high oxygen consumption of medaka (Figure 1). Marked increase in plasma osmolality (Figure 2) was observed at $96 \mathrm{~h}$ post-exposure.

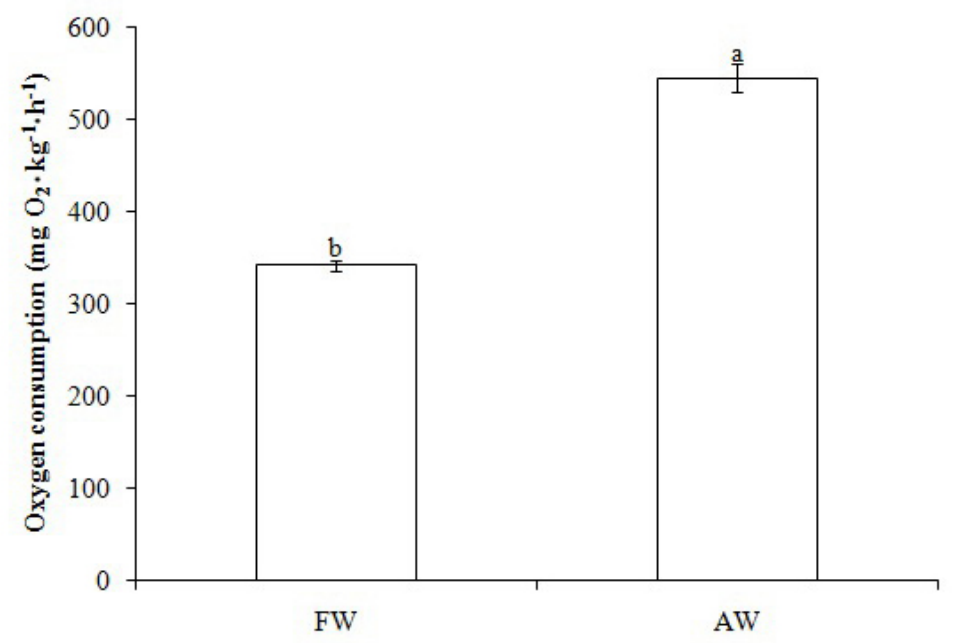

Figure 1. Oxygen consumption (means $\pm \mathrm{SEM}, \mathrm{N}=3$ ) of Oryzias latipes exposed to freshwater $(\mathrm{FW})$ and 30.4 $\mathrm{mM}$ carbonate alkalinity water (AW) for $96 \mathrm{~h}$. Different letters above the bars indicate statistically significant differences between means $(\mathrm{P}<0.05)$.

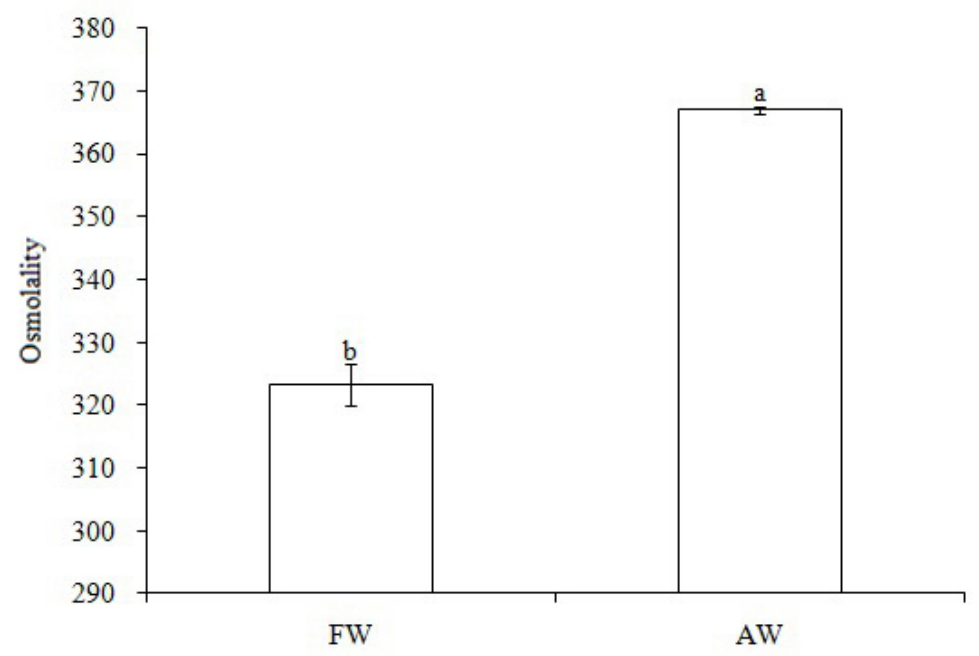

Figure 2. Plasma concentration of osmolality (means $\pm \mathrm{SEM}, \mathrm{N}=3$ ) in the blood of Oryzias latipes exposed to freshwater (FW) and $30.4 \mathrm{mM}$ carbonate alkalinity water (AW) for $96 \mathrm{~h}$. Different letters above the bars indicate statistically significant differences between means $(\mathrm{P}<0.05)$. 


\section{Alkalinity stress-responsive genes in medaka}

Gene expression profiles may reflect the interaction of environmental stresses and the host transcript (Gibson, 2008). Salinization of land and water owing to climate change has become a major problem in land and aquatic ecosystems worldwide. Alkalinity stress is considered to be one of the major stressors on fish in saline-alkali water. The detected signal intensities in the present study suggest that medaka gills had statistically significant gene expression under alkalinity stress compared to the control $(\mathrm{P}<0.05)$. Tests show that $3.8 \%(1013$ gene targets) of the features on the arrays were significantly different $(\mathrm{P}<0.05$, fold change $>1.5$ ) between the FW and AW treatment, of which 512 genes were up-regulated and 501 genes were down-regulated (see Supplementary Tables 1 and 2).

\section{Functional classification of the differentially expressed genes}

Most of differentially expressed genes identified in this study are listed as unknown in the annotation section of the GenBank database. Thus, we performed comparative genome analyses by retrieving these DNA sequences and comparing these genes against the KEGG database using $D$. rerio as the background species. In order to get more annotation information, a loose threshold $(\mathrm{P}<0.05$, fold change $>1.1)$ was used. This process yielded zebrafish orthologs $(\mathrm{E}<0.005)$ for $70 \%$ (1939) of differentially expressed medaka genes. These medaka genes were treated as known genes and their zebrafish counterparts' Entrez Gene IDs were used for GO grouping, and biological pathway analysis using D. rerio as the background species. One thousand and five differentially expressed genes match with annotated DAVID gene objects. Zebrafish IDs corresponding to differentially expressed medaka transcripts and to all genes represented on the array were then used to define a "gene list" and a "background" in DAVID. As the cut-off $\mathrm{P}$ value was set to count $=2$ and ease $=0.1$, the differently expressed genes fell into a number of GO groups on the second level.

As shown in Figure 3, there are 10 GO groups for up- and 6 for down-regulated genes. The number of up-regulated genes was higher than that of down-regulated genes. Most of the up-regulated genes were grouped into catalytic activity, metabolic process, cellular process, cell and cell part with the highest oxygen consumption rate (Figure 1), indicating that the alkalinity stress speeds up general metabolic and catalytic processing. The physiological responses of organisms to changes in environmental conditions, such as high $\mathrm{CO}_{2}$ (Todgham and Hofmann, 2009), osmotic stress (Evans, 2010; Lockwood et al., 2010), heat stress (Podrabsky and Somero, 2004), are energetic cost processes. In many fish species it is known that acclimation to hyper-saline water leads to an over-expression of the genes participating in osmoregulation as compared to the acclimation to iso-osmotic conditions (Evans, 2010). Indeed, fish acclimated to high carbonate alkalinity water face several pressures, including acid-base (Perry and Gilmour, 2006), osmolality disturbances (Figure 2) and ion imbalance (Goss et al., 1994). In this case, fish must maintain their homeostasis by activating energetically expensive ionic and osmotic regulation mechanisms. This is supported by the presence of several transcripts of genes encoding for ion binding proteins, such as carbonic anhydrase, glutathione-S-transferase and beta-type globin (Table 2). These proteins play a pivotal role in ionic regulation. On the other hand, identification of genes encoding for oxidation reduction such as cytochrome P450 suggests a high energetic demand for medaka acclimation to high alkalinity stress. 


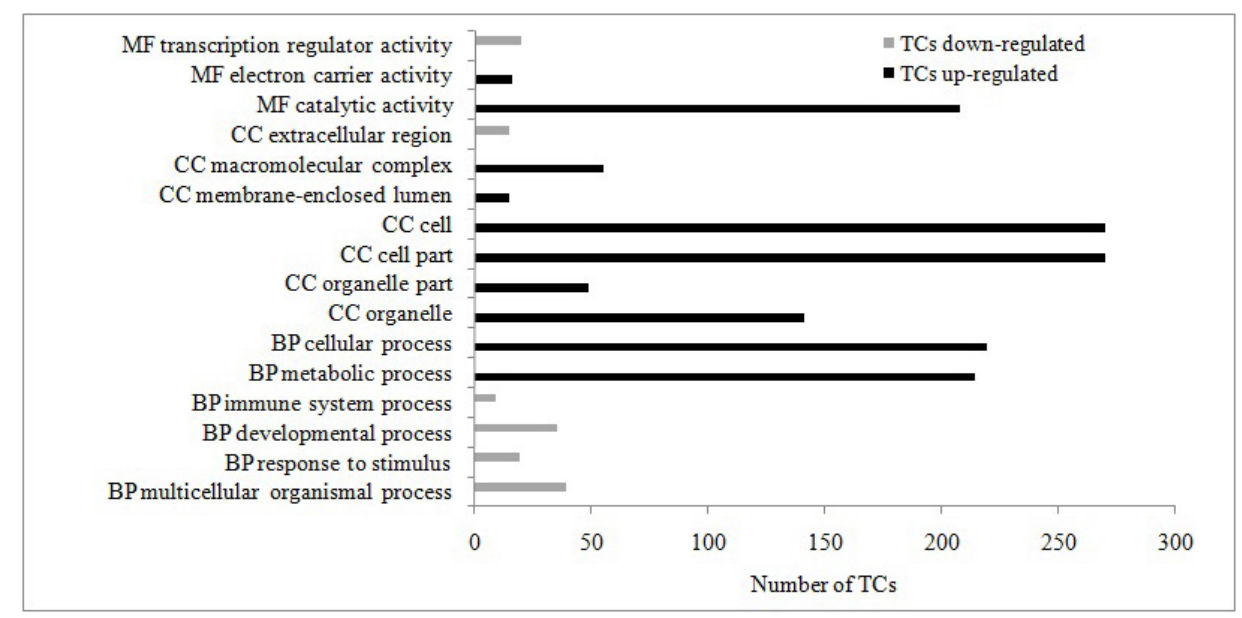

Figure 3. Number of gene ontology groups of medaka differentially expressed genes exposed to alkalinity stress. $\mathrm{MF}=$ Molecular function; $\mathrm{BP}=$ biological process $\mathrm{CC}=$ cellular component; $\mathrm{TCs}=$ Tentative Consensus sequences .

Table 2. Up-regulated genes in the gills of medaka exposed to carbonate alkalinity stress.

\begin{tabular}{|c|c|c|c|}
\hline TCs & Zebrafish Entrez Gene ID & Fold change & Gene name (Zebrafish description) \\
\hline \multicolumn{4}{|c|}{$\begin{array}{l}\text { Acid-base and ion } \\
\text { regulation }\end{array}$} \\
\hline TC64429 & 30331 & 1.57 & Carbonic anhydrase \\
\hline TC81188 & 791844 & 8.10 & Carbonic anhydrase XV b \\
\hline TC76034 & 564924 & 1.94 & ATPase, $\mathrm{Cu}^{2+}$ transporting, alpha polypeptide \\
\hline TC80873 & 448856 & 9.80 & $\mathrm{~S} 100$ calcium binding protein $\mathrm{A} 1$ \\
\hline TC86511 & 100150781 & 1.20 & Solute carrier family 30 (zinc transporter), member 5 \\
\hline TC74393 & 321324 & 1.45 & Solute carrier family 39 (zinc transporter), member 1 \\
\hline TC64151 & 368907 & 1.39 & Atpase, $\mathrm{H}^{+}$transporting, lysosomal, $\mathrm{V} 1$ subunit $\mathrm{C}$, isoform 1 \\
\hline TC80039 & 324140 & 4.20 & Serum/glucocorticoid regulated kinase 1 \\
\hline TC82123 & 777614 & 1.26 & Zgc:152898; similar to two pore calcium channel protein \\
\hline TC66488 & 555922 & 1.59 & $\begin{array}{l}\text { Similar to potassium voltage-gated channel, } \\
\text { Shaker-related subfamily, beta member } 1\end{array}$ \\
\hline TC67007 & 335821 & 1.46 & Zgc:8589; similar to aquaporin 1 \\
\hline \multicolumn{4}{|l|}{ Apoptosis } \\
\hline TC71948 & 559355 & 1.34 & BCL2-like 13 (apoptosis facilitator) \\
\hline TC67450 & 114401 & 1.18 & Bcl2-like \\
\hline TC77936 & 559018 & 1.46 & Clusterin-like \\
\hline TC85108 & 559007 & 1.12 & Death-associated protein 3 \\
\hline \multicolumn{4}{|l|}{ Cell cycle } \\
\hline TC72575 & 793158 & 1.54 & Cell division cycle 42 , like \\
\hline TC75544 & 445392 & 1.59 & F-box protein 5 \\
\hline TC71874 & 192295 & 1.56 & Cyclin A2 \\
\hline TC87801 & 368316 & 1.43 & Cyclin B2 \\
\hline TC63530 & 80973 & 1.40 & Cell division cycle 2 \\
\hline \multicolumn{4}{|c|}{ Cellular stress response } \\
\hline \multicolumn{4}{|c|}{ Protein homeostasis } \\
\hline TC66063 & 406294 & 1.14 & Glutaredoxin 5 homolog (Saccharomyces cerevisiae) \\
\hline TC77350 & 326857 & 1.63 & Glutamate-cysteine ligase, catalytic subunit \\
\hline TC87281 & 494477 & 2.39 & Transferrin receptor $1 \mathrm{a}$ \\
\hline TC74299 & 406289 & 1.33 & Thioredoxin domain containing 5 \\
\hline TC77854 & 565155 & 1.60 & Heat shock protein 90 -alpha 2 \\
\hline TC71195 & 321945 & 1.26 & AHA1, activator of heat shock protein atpase homolog 1 , like \\
\hline \multicolumn{4}{|c|}{ Antioxidant defense } \\
\hline TC77135 & 564619 & 1.23 & Transferrin-a; Rho-class glutathione S-transferase \\
\hline
\end{tabular}

Continued on next page 


\begin{tabular}{|c|c|c|c|}
\hline TCs & Zebrafish Entrez Gene ID & Fold change & Gene name (Zebrafish description) \\
\hline TC67219 & 406736 & 1.32 & Zgc:56518; similar to microsomal glutathione-S-transferase \\
\hline TC80729 & 325449 & 2.07 & Metallothionein 2; metallothionein; kinesin family member 20A \\
\hline TC66068 & 553575 & 1.72 & Zgc:110010; similar to glutathione reductase \\
\hline \multicolumn{4}{|c|}{$\begin{array}{l}\text { Toxicant, metal and } \\
\text { xenobiotic defense }\end{array}$} \\
\hline TC88886 & 406731 & 2.32 & $\begin{array}{l}\text { Zgc: } 123097 \text {; UDP glucuronosyltransferase } 1 \text { family a, b; UDP } \\
\text { glucuronosyltransferase } 1 \text { family }\end{array}$ \\
\hline TC63674 & 282559 & 1.69 & Aldehyde dehydrogenase 3 family, member D1 \\
\hline TC79029 & 553969 & 1.17 & Cytochrome P450, family 3 , subfamily A, polypeptide 65 \\
\hline TC76397 & 399485 & 12.67 & Cytochrome P450, family 2, subfamily J, polypeptide 21 \\
\hline TC66471 & 792041 & 1.15 & $\begin{array}{l}\text { Thromboxane A synthase } 1 \text { (platelet, cytochrome P450, family 5, } \\
\text { subfamily A) }\end{array}$ \\
\hline TC65409 & 406467 & 1.55 & ATP-binding cassette, subfamily F (GCN20), member 1 \\
\hline TC71048 & 100149614 & 1.44 & Similar to ATP-binding cassette, subfamily F (GCN20), member 3 \\
\hline \multicolumn{4}{|r|}{ 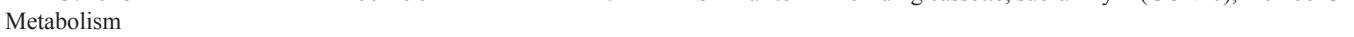 } \\
\hline \multicolumn{4}{|c|}{ Energy metabolism } \\
\hline TC86848 & 321664 & 2.04 & Aldolase $b$, fructose-bisphosphate \\
\hline TC79787 & 100003895 & 1.33 & ADP-ribosylation factor interacting protein 1 (arfaptin 1) \\
\hline \multicolumn{4}{|c|}{ Electron transport chain } \\
\hline TC87387 & 325922 & 1.15 & Retinol saturase (all-trans-retinol 13,14-reductase) \\
\hline TC86740 & 664750 & 1.43 & Protoporphyrinogen oxidase \\
\hline TC70864 & 140540 & 1.13 & Cytochrome c oxidase subunit 2 \\
\hline TC72168 & 555604 & 1.50 & NADPH oxidase 1 \\
\hline TC86017 & 393829 & 1.12 & NADH dehydrogenase (ubiquinone) 1 beta subcomplex, 8 \\
\hline TC62782 & 140531 & 1.84 & NADH-ubiquinone oxidoreductase chain 1 \\
\hline \multicolumn{4}{|c|}{$\begin{array}{l}\text { Mitochondrial membrane } \\
\text { transporters }\end{array}$} \\
\hline TC79031 & 100005717 & 1.29 & Carnitine palmitoyltransferase II \\
\hline TC73439 & 393638 & 1.29 & Translocase of inner mitochondrial membrane 50 homolog (yeast) \\
\hline TC62966 & 64607 & 1.97 & Aminolevulinate, delta-, synthetase 2 \\
\hline TC69117 & 394133 & 1.39 & Aldehyde dehydrogenase 4 family, member A1 \\
\hline TC76181 & 558883 & 1.16 & Translocated promoter region (to activated MET oncogene) \\
\hline TC79274 & 335236 & 1.36 & Transmembrane protein 48 \\
\hline TC67553 & 406852 & 1.31 & Nucleoporin 133 \\
\hline TC76902 & 337424 & 1.28 & ADP-ribosylation factor-like $8 \mathrm{Ba}$ \\
\hline \multicolumn{4}{|c|}{ Carbohydrate metabolism } \\
\hline TC66110 & 116991 & 2.24 & UDP-glucose dehydrogenase \\
\hline TC75325 & 678540 & 2.29 & UDP-galactose-4-epimerase \\
\hline TC73743 & 393461 & 2.23 & GDP-mannose 4,6-dehydratase \\
\hline TC64070 & 378727 & 1.98 & Phosphoenolpyruvate carboxykinase 1 (soluble) \\
\hline TC79120 & 791728 & 1.22 & Renin binding protein \\
\hline TC69528 & 445487 & 1.53 & Fucosidase, alpha-L-2, plasma \\
\hline TC65066 & 386663 & 1.85 & 6-phosphofructo-2-kinase/fructose-2,6-biphosphatase 4, like \\
\hline TC84984 & 570579 & 1.48 & Wu:fj78b06; similar to glucose-6-phosphate 1-dehydrogenase \\
\hline \multicolumn{4}{|c|}{ Amino acid metabolism } \\
\hline TC88744 & 393423 & 1.21 & Argininosuccinate lyase \\
\hline TC65754 & 447864 & 2.12 & $\begin{array}{l}\text { Argininosuccinate synthetase } 1 \text {; similar to argininosuccinate } \\
\text { synthetase }\end{array}$ \\
\hline TC87003 & 378847 & 1.30 & 5-methyltetrahydrofolate-homocysteine methyltransferase \\
\hline TC88179 & 550524 & 1.29 & Cystathionine-beta-synthase a \\
\hline TC65385 & 317738 & 3.06 & $\begin{array}{l}\text { ELOVL family member } 6 \text {, elongation of long chain fatty acids } \\
\text { (yeast) }\end{array}$ \\
\hline TC65615 & 266799 & 1.47 & Glycine amidinotransferase (L-arginine:glycine amidinotransferase) \\
\hline TC65820 & 566537 & 1.76 & Si:ch211-132p20.4; similar to amino acid system A transporter-like \\
\hline TC75021 & 100007704 & 1.83 & $\begin{array}{l}\text { Similar to solute carrier family } 7 \text { (cationic amino acid transporter, } \\
\mathrm{y}+\text { system), member } 8\end{array}$ \\
\hline TC67983 & 550373 & 1.21 & Peptidylprolyl isomerase E (cyclophilin E) \\
\hline \multicolumn{4}{|c|}{ Lipid metabolism } \\
\hline TC75954 & 445025 & 1.30 & Zgc:92251; similar to sodium/bile acid co-transporter 7 \\
\hline
\end{tabular}

Continued on next page 


\begin{tabular}{|c|c|c|c|}
\hline TCs & Zebrafish Entrez Gene ID & Fold change & Gene name (Zebrafish description) \\
\hline \multicolumn{4}{|c|}{ Vitamin metabolism } \\
\hline TC72880 & 30295 & 24.82 & Rhodopsin \\
\hline TC70178 & 777635 & 1.59 & Procollagen-lysine 1,2-oxoglutarate 5-dioxygenase 1a \\
\hline TC64004 & 403338 & 1.45 & Glycine N-methyltransferase \\
\hline TC63892 & 322055 & 2.80 & $\begin{array}{l}\text { Cystathionase (cystathionine gamma-lyase); cystathionase } \\
\text { (cystathionine gamma-lyase), like }\end{array}$ \\
\hline \multicolumn{4}{|c|}{ Nucleotide metabolism } \\
\hline TC63071 & 30733 & 1.53 & Ribonucleotide reductase M2 polypeptide \\
\hline TC70658 & 406383 & 1.89 & Cytidylate kinase \\
\hline TC76038 & 550560 & 1.82 & $\begin{array}{l}\text { Ectonucleoside triphosphate diphosphohydrolase } 6 \\
\text { (putative function) }\end{array}$ \\
\hline TC62666 & 550420 & 1.98 & Guanylate cyclase 1 , soluble, alpha 3 \\
\hline TC65833 & 393603 & 1.18 & cAMP-regulated phosphoprotein $19 a$ \\
\hline
\end{tabular}

TCs $=$ Tentative Consensus sequences.

Most of the down-regulated genes were grouped into multicellular organismal process, developmental process, transcription regulator activity, response to stimulus, extracellular region, and immune system process (Figure 3), indicating a decrease in disease resistance of medaka when exposed to carbonate alkalinity stress. Environmental stressors, such as salinity and heat stress, may cause immune suppression in aquatic animals (Prophete et al., 2006; Green and Barnes, 2010), and lead to maladaptation. The presence of several transcripts of genes encoding for immune response proteins, such as major histocompatibility complex (MHC), suggests that alkalinity stress has elicited an immune response in medaka fish.

In the section below, we describe the changes in mRNA expression in five main processes, including: acid-base and ion regulation, cellular stress response, metabolism, immune response, and reproduction (Tables 2 and 3). This custom category was based on the functional annotation clustering analysis by DAVID (classification stringency set as medium).

\section{Acid-base and ion regulation}

Regulation of ion transport proteins such as carbonic anhydrase, $\mathrm{Na}^{+}, \mathrm{K}^{+}$-ATPase and ATPase, $\mathrm{H}^{+}$transportation is essential to acid-base and osmoregulatory processes in fish (Kang et al., 2008; Gilmour and Perry, 2009). In this study, an 8.1- and 1.6-fold increase in mRNA of the CAXV and CA (carbonic anhydrase) was found during $96 \mathrm{~h}$ of high alkalinity stress. Carbonic anhydrase, a zinc enzyme that catalyzes reversible reactions of $\mathrm{CO}_{2}$ with water (Tufts et al., 2003), is responsible for converting $\mathrm{CO}_{2}$ into $\mathrm{HCO}_{3}^{-}$and $\mathrm{H}^{+}$ions. Carbonic anhydrase plays a key role in both acid-base and ionic regulation in fish by providing the acid-base equivalents that function as counter-ions for $\mathrm{NaCl}$ movement and that are excreted to maintain or restore acid-base balance at both the gills and kidney (Gilmour and Perry, 2009). Nitrogen end-products have diverse physiological functions in different animal groups, including acid-base regulation, osmoregulation and buoyancy. Animals excrete a variety of nitrogen waste products, such as ammonia, urea and uric acid. Aquatic animals excrete mostly ammonia. The major problems for fishes in alkaline water are the inhibition of ammonia excretion and increase in $\mathrm{CO}_{2}$ excretion (Parra and Baldisserotto, 2007). In alkali water, there is less $\mathrm{H}^{+}$available for transforming $\mathrm{NH}_{3}$ into $\mathrm{NH}_{4}^{+}$, so that the $\mathrm{NH}_{3}$ gradient from blood to water decreases. When medaka was placed in alkali water, a transitory metabolic alkalosis may occur, which resulted in the genes in nitrogen metabolism such as highly expressed CA2 mRNA to interconvert carbon dioxide and bicarbonate to maintain acid-base balance, and to facilitate carbon dioxide transport out of the gills. 
Table 3. Down-regulated genes in the gills of medaka exposed to carbonate alkalinity stress.

\begin{tabular}{|c|c|c|c|}
\hline TCs & Zebrafish Entrez Gene ID & Fold change & Gene name (Zebrafish description) \\
\hline \multicolumn{4}{|l|}{$\begin{array}{l}\text { Acid-base and } \\
\text { ion regulation }\end{array}$} \\
\hline TC65263 & 504083 & 1.38 & Zgc:110418; similar to potassium channel subfamily K member 6 \\
\hline TC77323 & 368255 & 1.48 & Chloride intracellular channel 4 \\
\hline \multicolumn{4}{|c|}{ Cellular stress response } \\
\hline \multicolumn{4}{|c|}{ Protein homeostasis } \\
\hline TC82521 & 799177 & 1.41 & Heat shock factor binding protein 1-like \\
\hline \multicolumn{4}{|c|}{ Toxicant, metal and } \\
\hline $\begin{array}{l}\text { xenobiotic de } \\
\text { TC74995 }\end{array}$ & 557525 & 1.58 & $\begin{array}{l}\text { Si:dkey-239i20.2; similar to flavin-containing monooxygenase } \\
\text { FMO1 }\end{array}$ \\
\hline TC87468 & 557008 & 1.22 & Novel protein similar to vertebrate aldehyde dehydrogenase 3 family \\
\hline TC68274 & 116713 & 1.37 & Aldehyde dehydrogenase 1 family, member $\mathrm{A} 2$ \\
\hline TC73159 & 447849 & 1.12 & Zgc:92194; similar to nuclear receptor coactivator 5 (ncoa-5) \\
\hline TC66847 & 565865 & 1.24 & Si:dkey-245f7.1; similar to nuclear receptor-interacting protein 2 \\
\hline TC64825 & 403010 & 1.71 & Nuclear receptor subfamily 0 , group $B$, member $2 a$ \\
\hline \multicolumn{4}{|l|}{ Development } \\
\hline TC79119 & 30037 & 1.66 & Similar to tenascin $\mathrm{C}$; tenascin $\mathrm{C}$ \\
\hline TC83533 & 570960 & 1.69 & Zgc:158824; pre-B-cell leukemia transcription factor 1a \\
\hline TC71844 & 100005469 & 1.59 & Fibronectin 1 \\
\hline TC75996 & 30264 & 1.67 & T-box gene 16 \\
\hline TC74173 & 566796 & 1.23 & Laminin, alpha 4 \\
\hline TC65915 & 554050 & 1.33 & Integrin, beta-like 1 \\
\hline TC64936 & 58150 & 1.46 & Heart and neural crest derivatives expressed transcript 2 \\
\hline TC68595 & 497649 & 1.56 & Transcription factor 7 (T-cell specific, HMG-box) \\
\hline TC78017 & 83496 & 1.62 & $\begin{array}{l}\text { BMP and activin membrane-bound inhibitor (Xenopus laevis) } \\
\text { homolog }\end{array}$ \\
\hline TC72996 & 799300 & 1.82 & Zgc:66156; similar to myosin heavy chain \\
\hline TC68178 & 335098 & 1.53 & Sprouty homolog 2 \\
\hline TC86481 & 386723 & 1.54 & Friend leukemia integration $1 \mathrm{~b}$ \\
\hline TC85163 & 569047 & 1.19 & Forkhead box plb \\
\hline TC69056 & 405843 & 1.36 & Forkhead box Q1 \\
\hline TC65686 & 393959 & 1.43 & Forkhead box L1 \\
\hline TC65627 & 30180 & 2.08 & Growth differentiation factor $6 \mathrm{~b}$ \\
\hline \multicolumn{4}{|l|}{ Kinome } \\
\hline TC69853 & 447930 & 1.80 & Zgc:103639; similar to myosin light chain 2 \\
\hline TC67029 & 406728 & 1.32 & Mitogen-activated protein kinase kinase 1 \\
\hline TC63675 & 100002318 & 1.34 & Im:7136778; similar to mitogen-activated protein kinase 13 \\
\hline TC69379 & 790934 & 2.15 & Mitogen-activated protein kinase-activated protein kinase 3 \\
\hline TC66976 & 553696 & 1.12 & $\begin{array}{l}\text { Zgc: } 112257 \text {; similar to LIM and senescent cell antigen-like } \\
\text { domains }\end{array}$ \\
\hline TC86513 & 393813 & 1.14 & PDZ and LIM domain 7 \\
\hline \multicolumn{4}{|c|}{ Metabolism } \\
\hline \multicolumn{4}{|c|}{ Energy metabolism } \\
\hline TC66930 & 553755 & 1.14 & $\begin{array}{l}\text { ATP synthase, } \mathrm{H}^{+} \text {transporting, mitochondrial } \mathrm{F} 1 \text { complex, alpha } \\
\text { subunit } 1 \text {, cardiac muscle }\end{array}$ \\
\hline \multicolumn{4}{|r|}{ subunt i, calciac miscie } \\
\hline TC64384 & 30497 & 1.32 & Lactate dehydrogenase B4 \\
\hline \multicolumn{4}{|c|}{ Amino acid metabolism } \\
\hline TC81763 & 335573 & 1.90 & Protein tyrosine phosphatase, non-receptor type 6 \\
\hline TC81376 & 568277 & 8.89 & SET binding factor 1 \\
\hline TC63031 & 334304 & 2.59 & Elastase 2-like \\
\hline TC70135 & 556307 & 2.05 & $\begin{array}{l}\text { Zgc: } 158605 \text {; serine (or cysteine) proteinase inhibitor, clade } \mathrm{E} \\
\text { (nexin, plasminogen activator inhibitor type } 1 \text { ), member } 2\end{array}$ \\
\hline TC62634 & 140425 & 1.54 & Guanylyl cyclase 2 \\
\hline TC69379 & 790934 & 2.15 & Mitogen-activated protein kinase-activated protein kinase 3 \\
\hline TC78001 & 100006858 & 1.57 & Casein kinase 1 , epsilon \\
\hline TC62864 & 335339 & 1.57 & Male germ cell-associated kinase \\
\hline TC71719 & 100000160 & 1.58 & Fibroblast growth factor receptor 4 \\
\hline TC 85640 & 325084 & 1.68 & $\begin{array}{l}\text { V-src sarcoma (Schmidt-Ruppin A-2) viral oncogene homolog } \\
\text { (avian) }\end{array}$ \\
\hline
\end{tabular}

Continued on next page 


\begin{tabular}{|c|c|c|c|}
\hline TCs & Zebrafish Entrez Gene ID & Fold change & Gene name (Zebrafish description) \\
\hline TC88729 & 558900 & 1.63 & RAB6B, member RAS oncogene family \\
\hline TC82622 & 541515 & 1.74 & Myosin 1b-like 2 \\
\hline TC69367 & 327396 & 1.77 & Ras-related associated with diabetes \\
\hline TC83650 & 100001337 & 1.67 & Slow myosin heavy chain 3 ; similar to slow myosin heavy chain 3 \\
\hline TC65046 & 335396 & 1.24 & Splicing factor, arginine/serine-rich $5 \mathrm{a}$ \\
\hline TC76014 & 794311 & 1.61 & Flavin containing monooxygenase 5 \\
\hline TC71098 & 322614 & 2.18 & Arginase, type II \\
\hline \multicolumn{4}{|c|}{ Lipid metabolism } \\
\hline TC67400 & 442923 & 1.45 & 3-oxoacid coa transferase 1a \\
\hline TC66334 & 402958 & 1.28 & Zgc:77336; im:7142624; similar to probable lipid phosphate \\
\hline \multicolumn{4}{|c|}{ Phosphatase PPAPDC3 } \\
\hline TC84023 & 324345 & 1.56 & Wu:fc26c03; similar to choline transporter-like protein 2 \\
\hline \multicolumn{4}{|c|}{ Vitamin metabolism } \\
\hline TC65526 & 558106 & 1.34 & $\begin{array}{l}\text { Hypothetical LOC558106; similar to vitamin K-dependent } \\
\text { protein Z precursor }\end{array}$ \\
\hline \multicolumn{4}{|c|}{ Nucleotide metabolism } \\
\hline TC86873 & 492467 & 1.62 & $\begin{array}{l}\text { Guanine nucleotide binding protein (G protein), alpha activating } \\
\text { activity polypeptide, olfactory type }\end{array}$ \\
\hline TC79351 & 406251 & 1.63 & RNA binding motif protein $39 \mathrm{a}$ \\
\hline \multicolumn{4}{|c|}{$\begin{array}{l}\text { Protein synthesis - } \\
\text { translational control }\end{array}$} \\
\hline TC64820 & 322237 & 1.12 & Eukaryotic translation initiation factor $1 \mathrm{~B}$ \\
\hline TC69371 & 562897 & 1.65 & Similar to RIKEN cdna 2810012L14 \\
\hline TC85263 & 436759 & 1.59 & Ribosomal protein L38 \\
\hline \multicolumn{4}{|c|}{ Immune response } \\
\hline TC65777 & 368614 & 1.43 & Si:busm1-194e12.11; similar to MHC class II alpha subunit \\
\hline TC62736 & 550387 & 2.51 & Zgc:111997 \\
\hline TC80282 & 571282 & 1.74 & $\begin{array}{l}\text { Similar to H-2 class II histocompatibility antigen, A-K alpha } \\
\text { chain; novel protein with a class II histocompatibility antigen, } \\
\text { alpha domain and an immunoglobulin } \mathrm{C} 1 \text {-set domain }\end{array}$ \\
\hline TC83664 & 100003911 & 2.09 & Chemokine CXCL-c13d \\
\hline TC73740 & 553699 & 2.38 & Vitronectin a \\
\hline TC81021 & 541408 & 1.73 & Similar to marapsin; zgc: 101788 \\
\hline TC67829 & 58113 & 1.70 & Invariant chain-like protein 1 \\
\hline TC69939 & 30553 & 1.38 & Superoxide dismutase 1 , soluble \\
\hline \multicolumn{4}{|l|}{ Reproduction } \\
\hline TC75004 & 445065 & 5.28 & $\begin{array}{l}\text { Hypothetical protein LOC100151043; corticotropin-releasing } \\
\text { hormone binding protein }\end{array}$ \\
\hline TC66699 & 572500 & 1.29 & Similar to RAS-like, estrogen-regulated, growth inhibitor \\
\hline
\end{tabular}

TCs $=$ Tentative Consensus sequences.

The serum and glucocorticoid regulated kinase 1 (SGK-1) gene that plays an important role in ion homeostasis (Lang et al., 2006) was significantly up-regulated by high alkalinity stress. SGK-1 plays an important role in the regulation of epithelial ion transport, such as $\mathrm{Na}^{+}$handling in renal tubular of mice (Loffing et al., 2006). This kinase is rapidly regulated at the transcriptional level. In addition, SGK-1 may influence the activities of other ion-transporters such as the $\mathrm{Na}^{+}-\mathrm{K}^{+}$-ATPase, $\mathrm{Na}^{+} / \mathrm{H}^{+}$exchanger and $\mathrm{Na}^{+} / \mathrm{K}^{+} / \mathrm{Cl}^{-}$co-transporters (Lang et al., 2006). These properties allow SGK-1 to integrate numerous signaling inputs into varied cellular responses.

The mitogen-activated protein kinase (MAPK) is a family of enzymes that are involved in osmosensory signal transduction in yeast, vertebrates and other eukaryotes (Kültz, 2001). They are key elements of protein phosphorylation cascades that integrate and amplify signals from osmosensors to activate appropriate downstream targets mediating physiological acclimation (Kültz, 2001). It plays an important role in osmosensory signal transduction in fish (Fiol and Kültz, 2007). Under high alkalinity stress, MAPK1 and MAPK3 MAPK13 mRNA expression in medaka gill tissue were down-regulated 1.3-2.15-fold (Table 3). The decrease 
in MAPK expression was backed by a coincident decrease of other MAPK relevant genesphosphatidic acid phosphatase 2, together with the increase of the plasma osmolality (Figure 2 ), indicating a stimulation of acid-base and ion regulation of madaka under alkalinity stress.

\section{Cellular stress response}

Several cellular stress response-related genes of medaka were differentially expressed during alkalinity stress, such as, protein homeostasis, antioxidant defense and toxicant, metal and xenobiotic defense (Table 2). The cellular stress response is a universal mechanism of extraordinary physiological/pathophysiological significance. It represents a defense reaction of cells to environmental forces inflicted on macromolecules (Kültz, 2005). Medaka may turn on its defense system in response to relative high alkalinity stress, but mortality increases greatly when the alkalinity exceeds its tolerance (Yao et al., 2010). At a cellular level, cells can quantify stress and activate a death program (apoptosis) when tolerance limits are exceeded.

\section{Metabolism}

As mentioned above, the alkalinity stress speeded up general metabolic and catalytic processes of medaka. Fish gills are highly oxidative tissues, and their oxygen requirement increases when fishes are exposed to environmental stresses, such as salinity (Vijayan et al., 1996). The energy requirement for the gills is through oxidation of glucose and lactate obtained from the circulation (Tseng and Hwang, 2008). When fishes are exposed to alkalinity stress, the glycolysis process is up-regulated by carbohydrate metabolism (Table 2), so medaka may spend more energy under alkalinity stress.

Lipid phosphate phosphatase (LPPs) regulates cell signaling by modifying the concentrations of lipid phosphates versus the dephosphorylated products (Brindley and Pilquil, 2009). LPP mRNA was down-regulated under high alkalinity stress in medaka gill tissue (Table 3), which is similar to Gillichthys mirabilis exposed to hyper- and hypo-osmotic stress (Evans, 2010).

\section{Immune response}

MHC belongs to the immunoglobulin superfamily of proteins, and interacts with the T-cell subsets through a specific T-cell receptor (TCR), and initiates the adaptive immune response (Kurosawa and Hashimoto, 1997). MHC has been studied intensively, and is consequently one of the best characterized genetic complexes in vertebrates because of its key function in the immune response. MHC gene expression is always down-regulated when medaka fish are exposed to environmental stresses, such as low temperature (Rodrigues et al., 1998). Because MHC class II antigens play an important role in generating an immune response to bacterial and fungal pathogens, down-regulation of these genes during alkalinity stress probably accounts for the susceptibility of fish to alkalinity-related diseases such as Prymnesium parvum. How salinity or alkalinity up- or down-regulates the immune responses remains unknown. In this study, MHC class II and invariant chain-like protein I (Table 3) were downregulated when medaka was exposed to high alkalinity, indicating that the immune system response of medaka was slowed down under this kind of stress. 


\section{Reproduction}

Some genes taking part in the regulation of gonadotropin gene expression were downregulated in medaka exposed to alkalinity stress. The genes involved in GnRH (gonadotropin-releasing hormone) signaling pathway including mitogen-activated protein kinase, v-src sarcoma viral oncogene homolog, and matrix metalloproteinase 14 beta were down-regulated (Table 3). And other genes playing important roles in fish reproduction, such as corticotropinreleasing hormone binding protein and estrogen-regulated gene were down-regulated (Table 3). Dysregulation of these genes agrees with our previous results that reproduction of medaka was inhibited under high carbonate alkalinity stress (Yao et al., 2010).

As the cut-off $P$ value was set to $<0.05$, count $=2$ and ease $=0.1$, we found that 10 pathways were up-regulated significantly in dealing with alkalinity stress, including amino sugar and nucleotide sugar metabolism, porphyrin and chlorophyll metabolism, metabolism of xenobiotics by cytochrome P450, drug metabolism, aminoacyl-tRNA biosynthesis, glycine, serine and threonine metabolism, ascorbate and aldarate metabolism, pentose and glucuronate interconversions, glutathione metabolism, and fructose and mannose metabolism (Table 4).

Table 4. Up-regulated pathways in the gills of medaka exposed to carbonate alkalinity stress.

\begin{tabular}{lcc}
\hline Target & Genes found (N) & P value \\
\hline Amino sugar and nucleotide sugar metabolism & 11 & $4.65 \mathrm{E}-05$ \\
Porphyrin and chlorophyll metabolism & 8 & $3.35 \mathrm{E}-04$ \\
Metabolism of xenobiotics by cytochrome P450 & 6 & 0.0033 \\
Drug metabolism & 6 & 0.0033 \\
Aminoacyl-tRNA biosynthesis & 7 & 0.0076 \\
Glycine, serine and threonine metabolism & 6 & 0.0130 \\
Ascorbate and aldarate metabolism & 4 & 0.0174 \\
Pentose and glucuronate interconversions & 4 & 0.0219 \\
Glutathione metabolism & 6 & 0.0303 \\
Fructose and mannose metabolism & 6 & 0.0408 \\
\hline
\end{tabular}

\section{Real-time PCR validation}

The validation involved qPCR analysis of mRNA abundance for 10 genes. The directionality of responses to alkalinity stress obtained through qPCR is in full agreement with microarrays. As shown in Figure 4, inductions and suppressions of the gene expression were in line with the microarray data.

\section{CONCLUSION}

To our knowledge, this is the first study employing a medaka high-density oligonucleotide microarray to detect global gene expression alterations in response to alkalinity stress. Alkalinity stress stimulated the energy and ion regulated processes, and slowed down the gene expression related to the immune system and reproduction in medaka. The alkalinity-regulated genes characterized in the present study may be convenient entry points to study the molecular basis of alkalinity stress. The physiological role of these genes in alkalinity stress response remains to be explored. In the future, how alkalinity triggers regulation of expression of these genes needs to be addressed. 


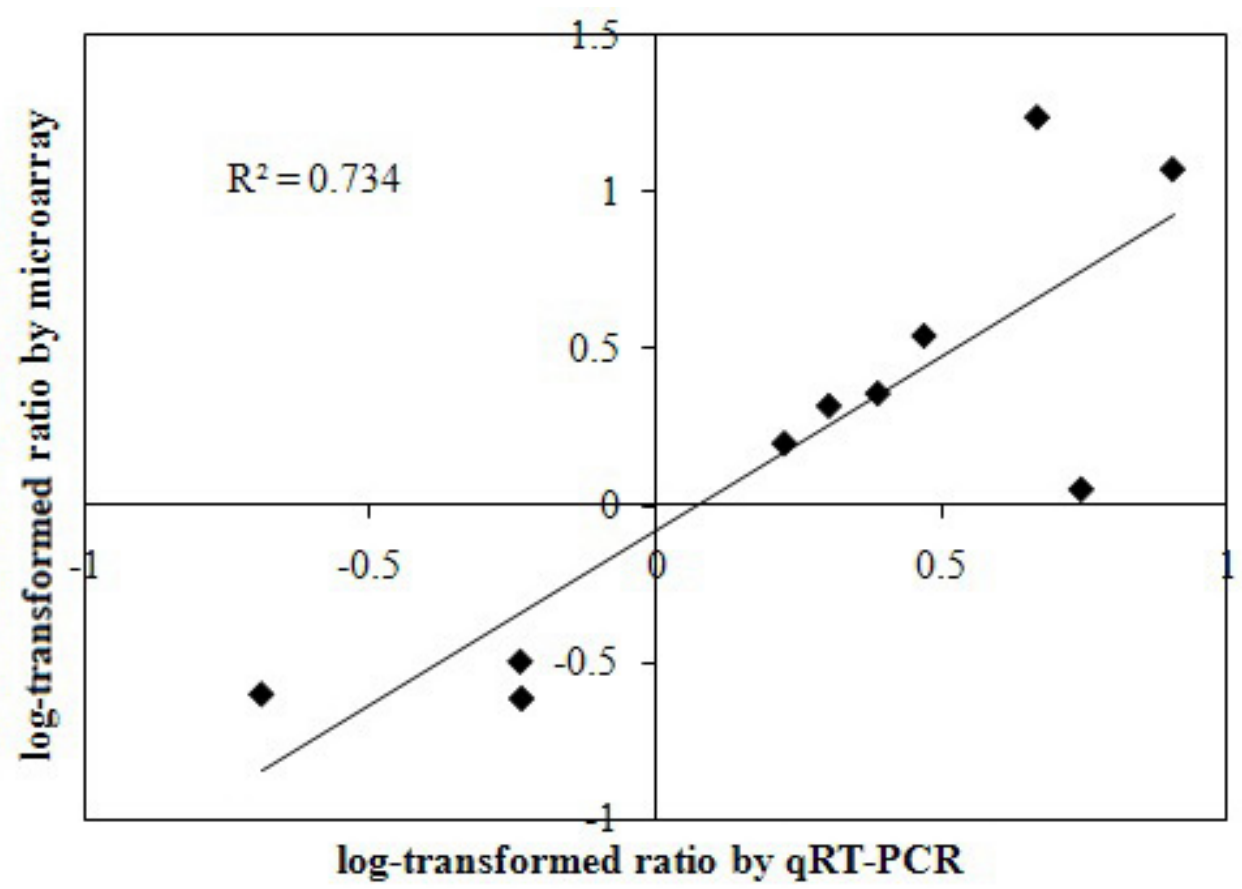

Figure 4. Scatter plot comparing the log-transformed ratio measured by qRT-PCR analysis (x-axis) and by microarray (y-axis). $\mathrm{R}^{2}=0.734$.

\section{ACKNOWLEDGMENTS}

Research supported by special research fund for the national non-profit institutes (East China Sea Fisheries Research Institute) (Project \#2009M03, \#2007Z03), special fund for agroscientific research in the public interest (\#200903001-0502), Hydrobiological Project of Shanghai Leading Academic Discipline III (\#S30701). We thank Prof. Kiyoshi Naruse for his advice on medaka microarray design and Dr. D. Zhang and Prof. Jinru Ma for their advice on an early draft of the manuscript. Q. Ding took care of the experimental fish daily. We also express our sincere gratitude to everyone involved in the construction of the Oryzias latipes Gene Index and to the molecular biologists who generated medaka TCs and ESTs.

\section{REFERENCES}

Brindley DN and Pilquil C (2009). Lipid phosphate phosphatases and signaling. J. Lipid. Res. 50: S225-S230.

Claiborne JB, Edwards SL and Morrison-Shetlar AI (2002). Acid-base regulation in fishes: cellular and molecular mechanisms. J. Exp. Zool. 293: 302-319.

Dennis G Jr, Sherman BT, Hosack DA, Yang J, et al. (2003). DAVID: Database for Annotation, Visualization, and Integrated Discovery. Genome Biol. 4: 3.

Evans TG (2010). Co-ordination of osmotic stress responses through osmosensing and signal transduction events in fishes. J. Fish Biol. 76: 1903-1925.

Fiol DF and Kültz D (2007). Osmotic stress sensing and signaling in fishes. FEBS J. 274: 5790-5798.

Gibson G (2008). The environmental contribution to gene expression profiles. Nat. Rev. Genet. 9: 575-581. 
Gilmour KM and Perry SF (2009). Carbonic anhydrase and acid-base regulation in fish. J. Exp. Biol. 212: 1647-1661.

Goss GG, Wood CM, Laurent P and Perry SF (1994). Morphological responses of the rainbow trout (Oncorhynchus mykiss) gill to hyperoxia, base $\left(\mathrm{NaHCO}_{3}\right)$ and acid $(\mathrm{HCl})$ infusions. Fish Physiol. Biochem. 12: 465-477.

Green TJ and Barnes AC (2010). Reduced salinity, but not estuarine acidification, is a cause of immune-suppression in the Sydney rock oyster Saccostrea glomerata. Mar. Ecol. Prog. Ser. 402: 161-170.

Hirayama M, Nakaniwa M, Mitani H and Watabe S (2005). Gene expression profiles for medaka Olyzias latipes associated with cold and warm temperatures in cDNA microarray. Comp. Biochem. Phys. 141: S354-S355.

Hwang PP and Lee TH (2007). New insights into fish ion regulation and mitochondrion-rich cells. Comp. Biochem. Physiol. A Mol. Integr. Physiol. 148: 479-497.

Inoue K and Takei Y (2002). Diverse adaptability in oryzias species to high environmental salinity. Zoolog. Sci. 19: 727734.

Kanehisa M and Goto S (2000). KEGG: kyoto encyclopedia of genes and genomes. Nucleic Acids Res. 28: 27-30.

Kang CK, Tsai SC, Lee TH and Hwang PP (2008). Differential expression of branchial $\mathrm{Na}^{+} / \mathrm{K}^{+}$-ATPase of two medaka species, Oryzias latipes and Oryzias dancena, with different salinity tolerances acclimated to fresh water, brackish water and seawater. Comp. Biochem. Physiol. A Mol. Integr. Physiol. 151: 566-575.

Kasahara M, Naruse K, Sasaki S, Nakatani Y, et al. (2007). The medaka draft genome and insights into vertebrate genome evolution. Nature 447: 714-719.

Kültz D (2001). Evolution of osmosensory MAP kinase signaling pathways. Am. Zool. 41: 743-757.

Kültz D (2005). Molecular and evolutionary basis of the cellular stress response. Annu. Rev. Physiol. 67: 225-257.

Kurosawa Y and Hashimoto K (1997). How did the primordial T cell receptor and MHC molecules function initially? Immunol. Cell Biol. 75: 193-196.

Lang F, Bohmer C, Palmada M, Seebohm G, et al. (2006). (Patho)physiological significance of the serum- and glucocorticoid-inducible kinase isoforms. Physiol. Rev. 86: 1151-1178.

Lockwood BL, Sanders JG and Somero GN (2010). Transcriptomic responses to heat stress in invasive and native blue mussels (genus Mytilus): molecular correlates of invasive success. J. Exp. Biol. 213: 3548-3558.

Loffing J, Flores SY and Staub O (2006). Sgk kinases and their role in epithelial transport. Annu. Rev. Physiol. 68: 461490.

Parra JEG and Baldisserotto B (2007). Effect of Water pH and Hardness on Survival and Growth of Freshwater Teleosts. In: Fish Osmoregulation (Baldisserotto B, Mancera JM and Kapoor BG, eds.). Science Publishers, Enfield, 139.

Perry SF and Gilmour KM (2006). Acid-base balance and $\mathrm{CO}_{2}$ excretion in fish: unanswered questions and emerging models. Respir. Physiol. Neurobiol. 154: 199-215.

Podrabsky JE and Somero GN (2004). Changes in gene expression associated with acclimation to constant temperatures and fluctuating daily temperatures in an annual killifish Austrofundulus limnaeus. J. Exp. Biol. 207: 2237-2254.

Prophete C, Carlson EA, Li Y, Duffy J, et al. (2006). Effects of elevated temperature and nickel pollution on the immune status of Japanese medaka. Fish Shellfish Immunol. 21: 325-334.

Randall DJ and Tsui TK (2006). Tribute to R. G. Boutilier: acid-base transfer across fish gills. J. Exp. Biol. 209: 11791184.

Rodrigues PN, Hermsen TT, van Maanen A, Taverne-Thiele AJ, et al. (1998). Expression of MhcCyca class I and class II molecules in the early life history of the common carp (Cyprinus carpio L.). Dev. Comp. Immunol. 22: 493-506.

Rozen S and Skaletsky HJ (2000). Primer 3 on the WWW for General Users and for Biologist Programmers. In: Bioinformatics Methods and Protocols: Methods in Molecular Biology (Krawetz S and Misener S, eds.). Humana Press, Totowa, 365-386.

Schmittgen TD and Livak KJ (2008). Analyzing real-time PCR data by the comparative $\mathrm{C}_{\mathrm{T}}$ method. Nat. Protoc. 3: 11011108 .

Scott GR, Richards JG, Forbush B, Isenring P, et al. (2004). Changes in gene expression in gills of the euryhaline killifish Fundulus heteroclitus after abrupt salinity transfer. Am. J. Physiol. Cell Physiol. 287: C300-C309.

Takeda H and Shimada A (2010). The art of medaka genetics and genomics: what makes them so unique? Annu. Rev. Genet. 44: 217-241.

Todgham AE and Hofmann GE (2009). Transcriptomic response of sea urchin larvae Strongylocentrotus purpuratus to $\mathrm{CO}_{2}$-driven seawater acidification. J. Exp. Biol. 212: 2579-2594.

Tseng YC and Hwang PP (2008). Some insights into energy metabolism for osmoregulation in fish. Comp. Biochem. Physiol. C Toxicol. Pharmacol. 148: 419-429.

Tufts BL, Esbaugh A and Lund SG (2003). Comparative physiology and molecular evolution of carbonic anhydrase in the erythrocytes of early vertebrates. Comp. Biochem. Physiol. A Mol. Integr. Physiol. 136: 259-269.

Vijayan M, Morgan J, Sakamoto T, Grau E, et al. (1996). Food-deprivation affects seawater acclimation in tilapia: hormonal and metabolic changes. J. Exp. Biol. 199: 2467-2475. 
Wang YS, Gonzalez RJ, Patrick ML, Grosell M, et al. (2003). Unusual physiology of scale-less carp, Gymnocypris przewalskii, in Lake Qinghai: a high altitude alkaline saline lake. Comp. Biochem. Physiol. A Mol. Integr. Physiol. 134: 409-421.

Wilkie MP and Wood CM (1996). The adaptations of fish to extremely alkaline environments. Comp. Biochem. Phys. B 113: 665-673.

Yao ZL, Lai QF, Zhou K, Rizalita RE, et al. (2010). Developmental biology of medaka fish (Oryzias latipes) exposed to alkalinity stress. J. Appl. Ichthyol. 26: 397-402.

Yum S, Woo S, Kagami Y, Park HS, et al. (2010). Changes in gene expression profile of medaka with acute toxicity of Arochlor 1260, a polychlorinated biphenyl mixture. Comp. Biochem. Physiol. C Toxicol. Pharmacol. 151: 51-56.

Zhang Z, Ju Z, Wells MC and Walter RB (2009). Genomic approaches in the identification of hypoxia biomarkers in model fish species. J. Exp. Mar. Biol. Ecol. 381: S180-S187. 
Transcriptomic profile of $O$. latipes after alkalinity stress

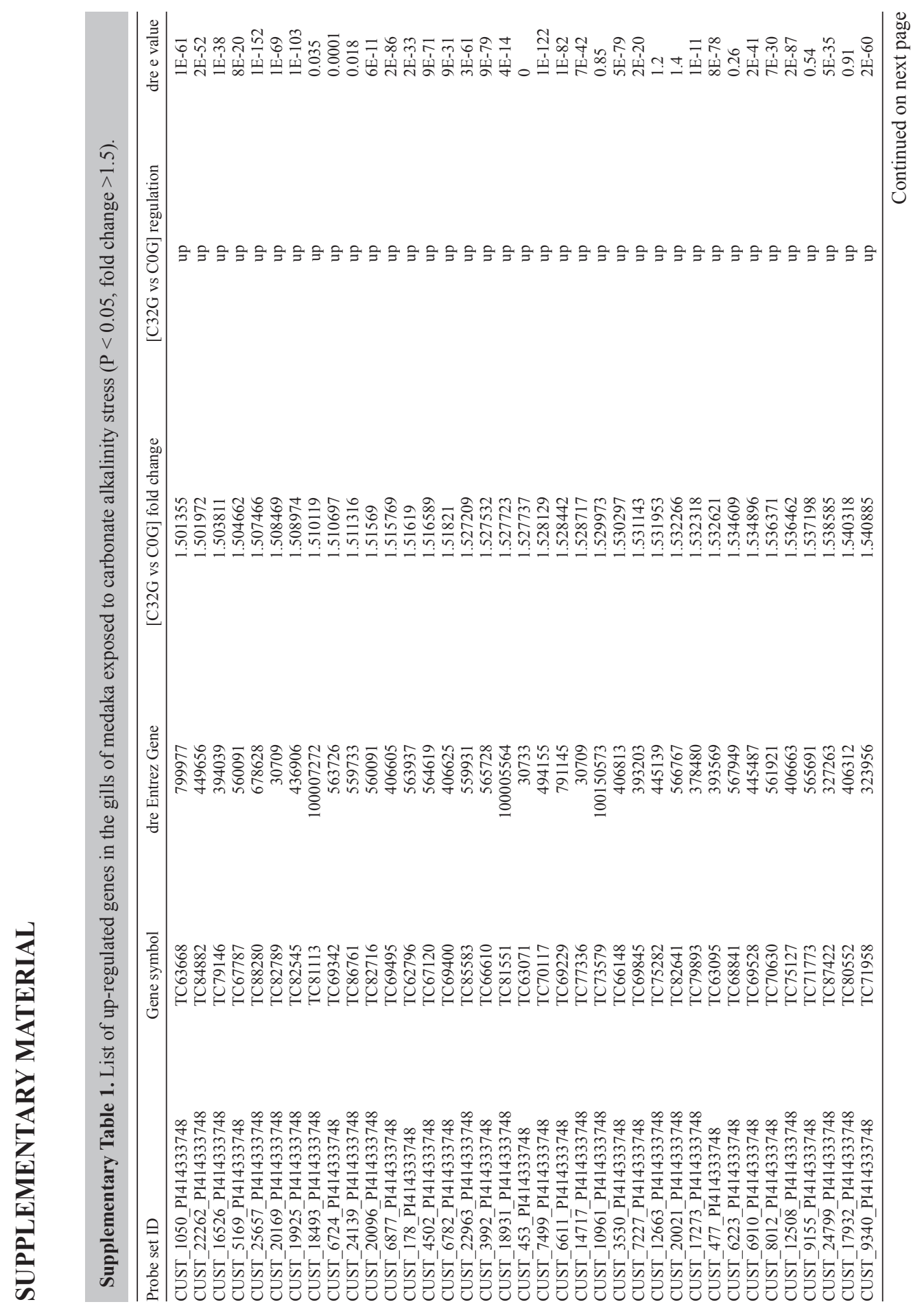

Genetics and Molecular Research 11 (3): 2200-2246 (2012)

CFUNPEC-RP www.funpecrp.com.br 


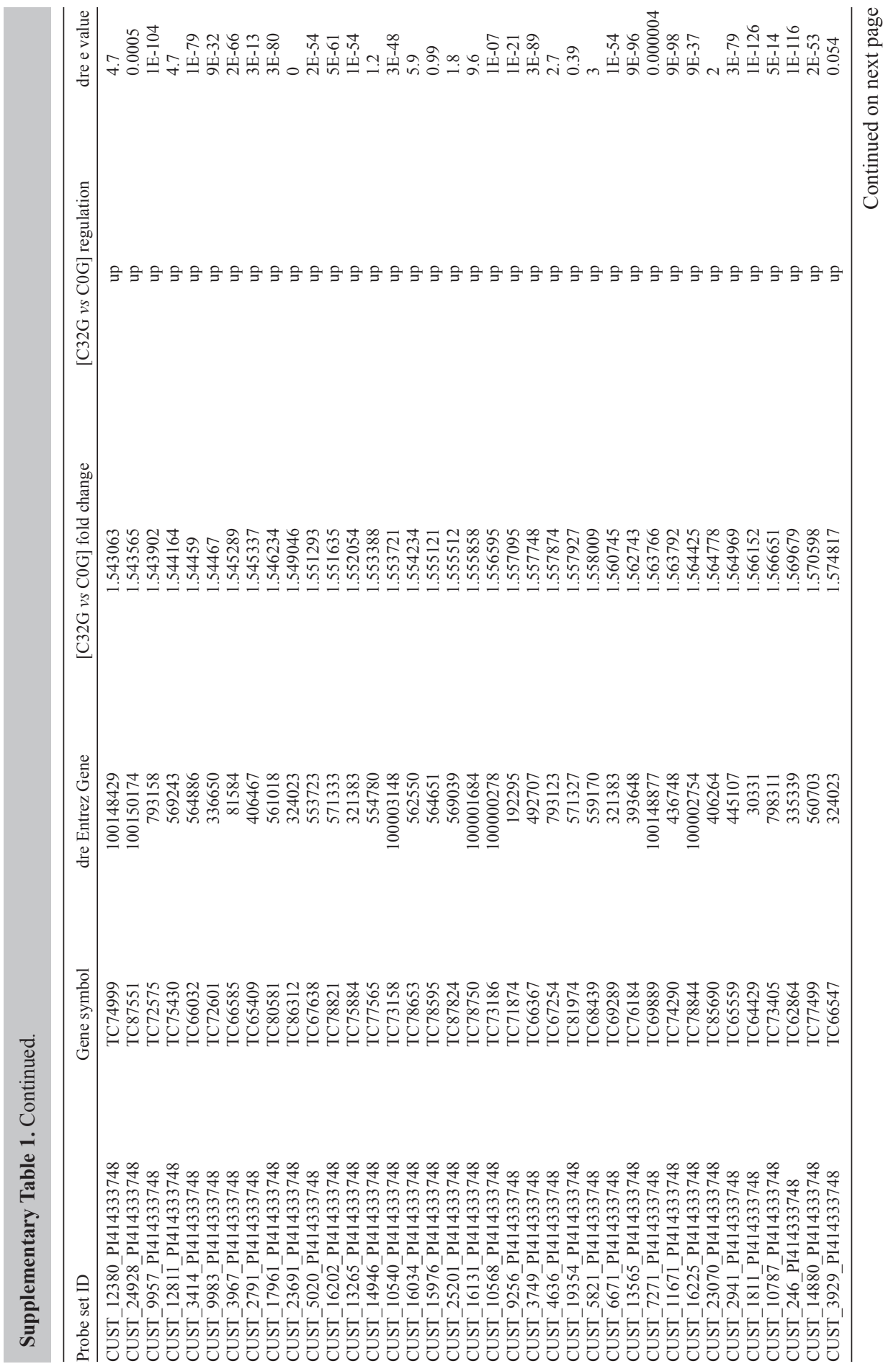




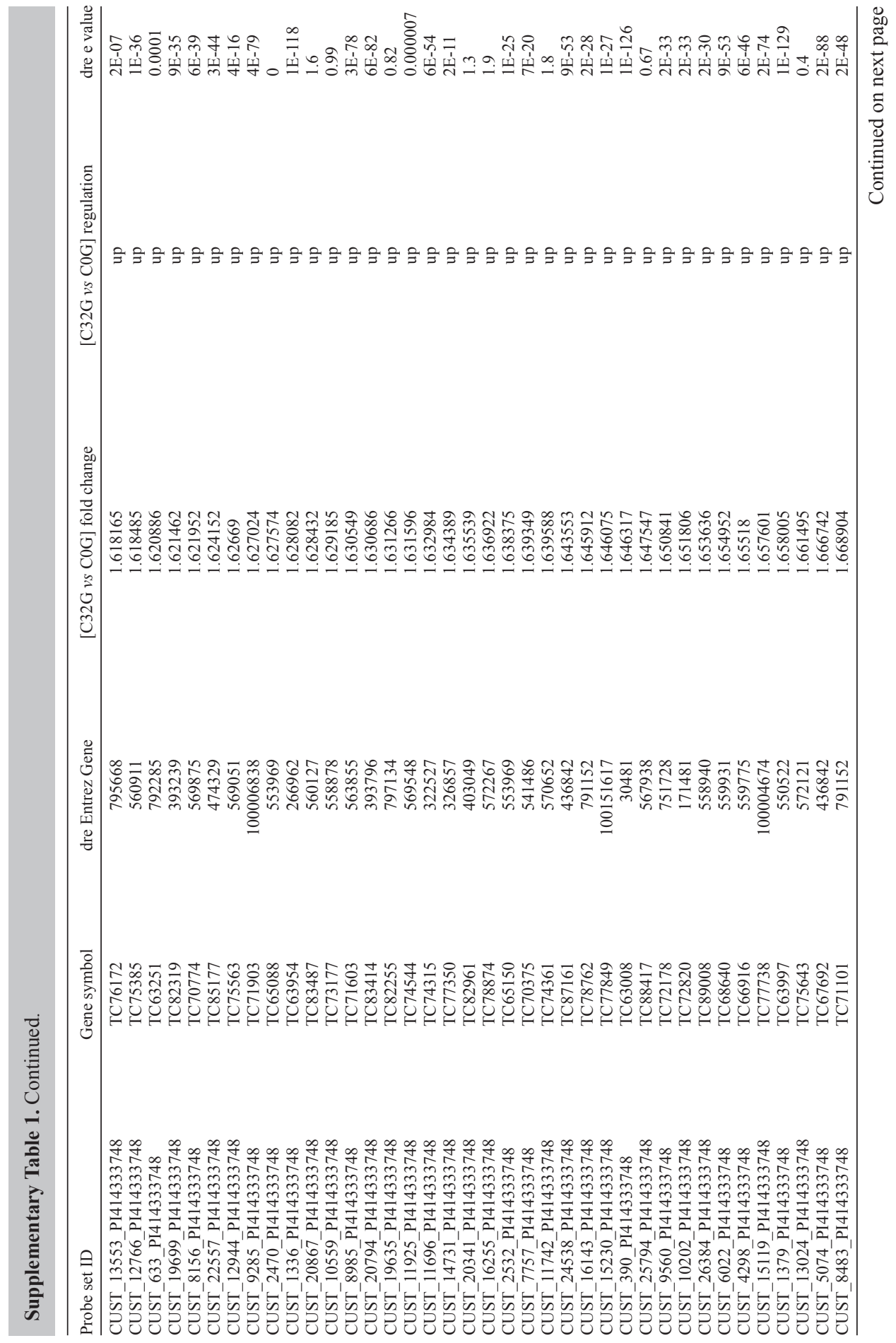




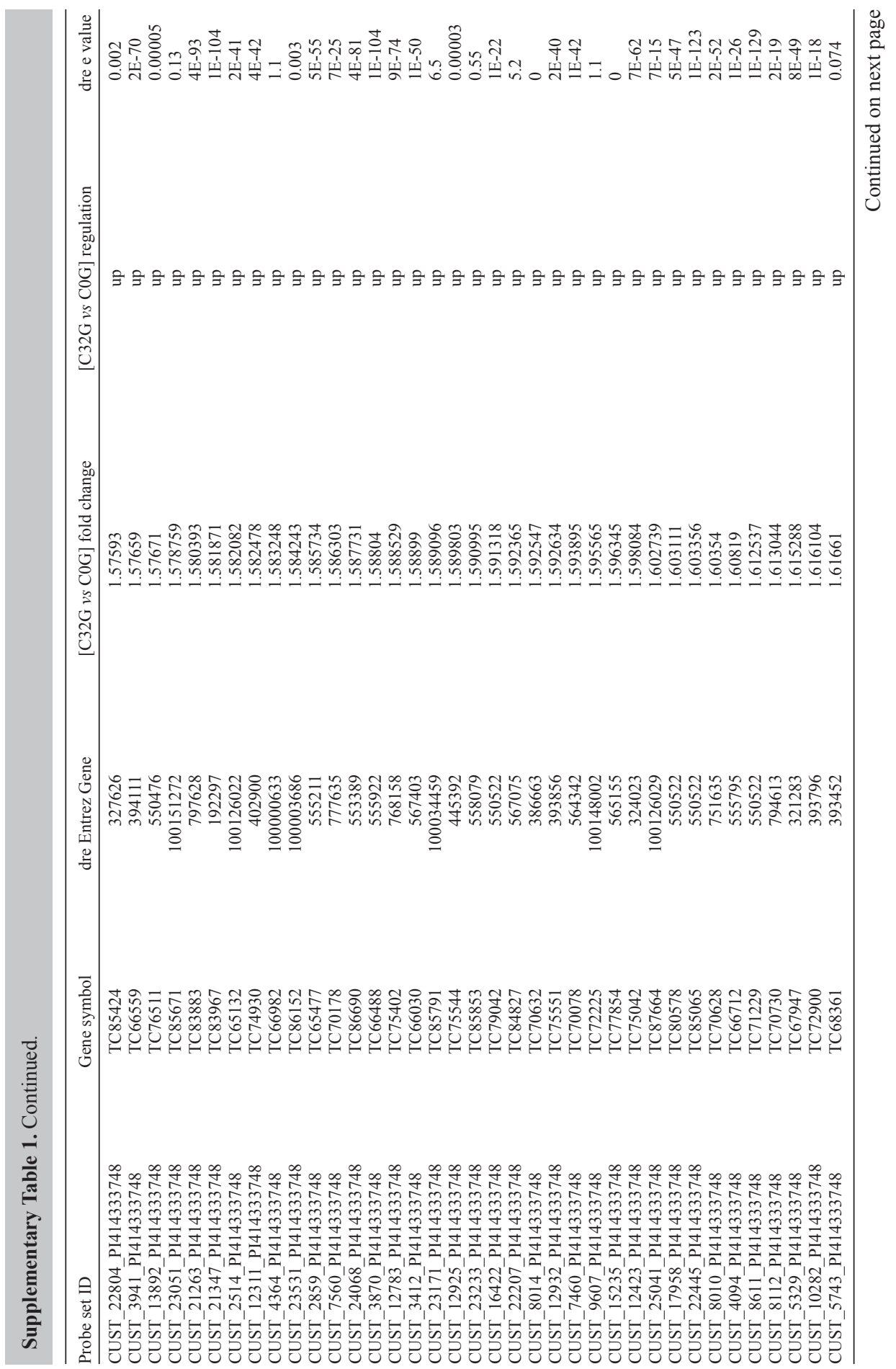




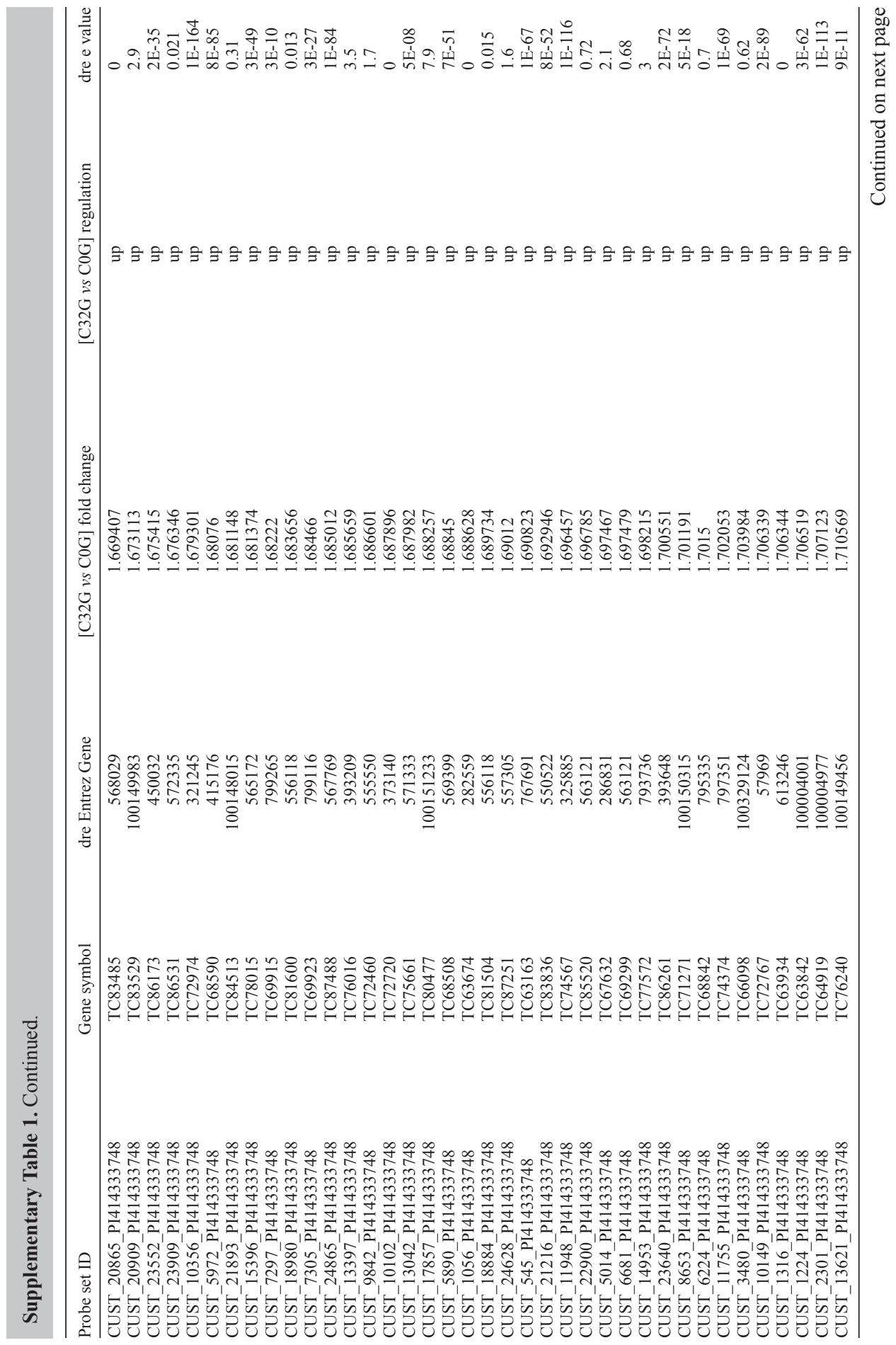




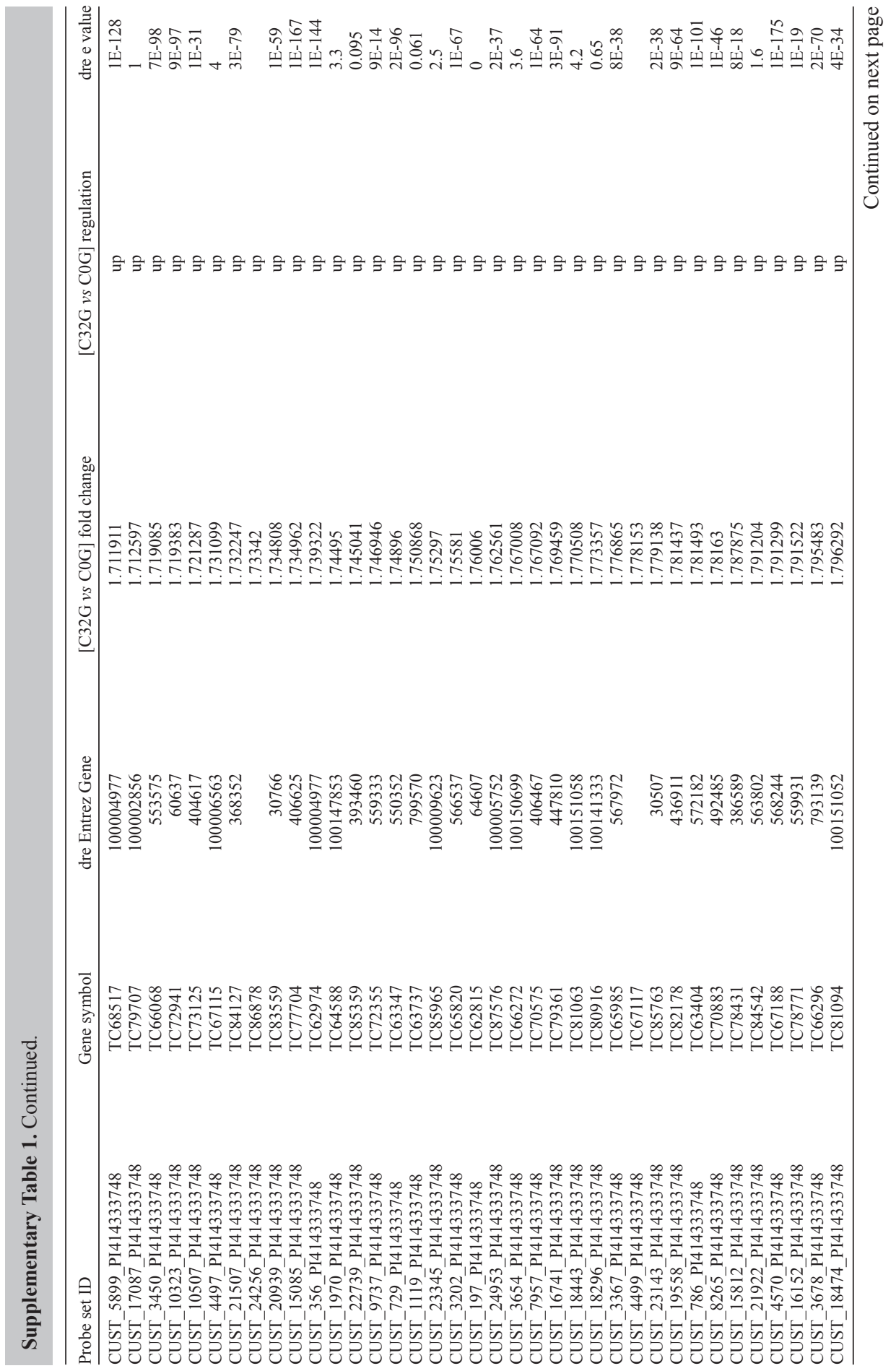




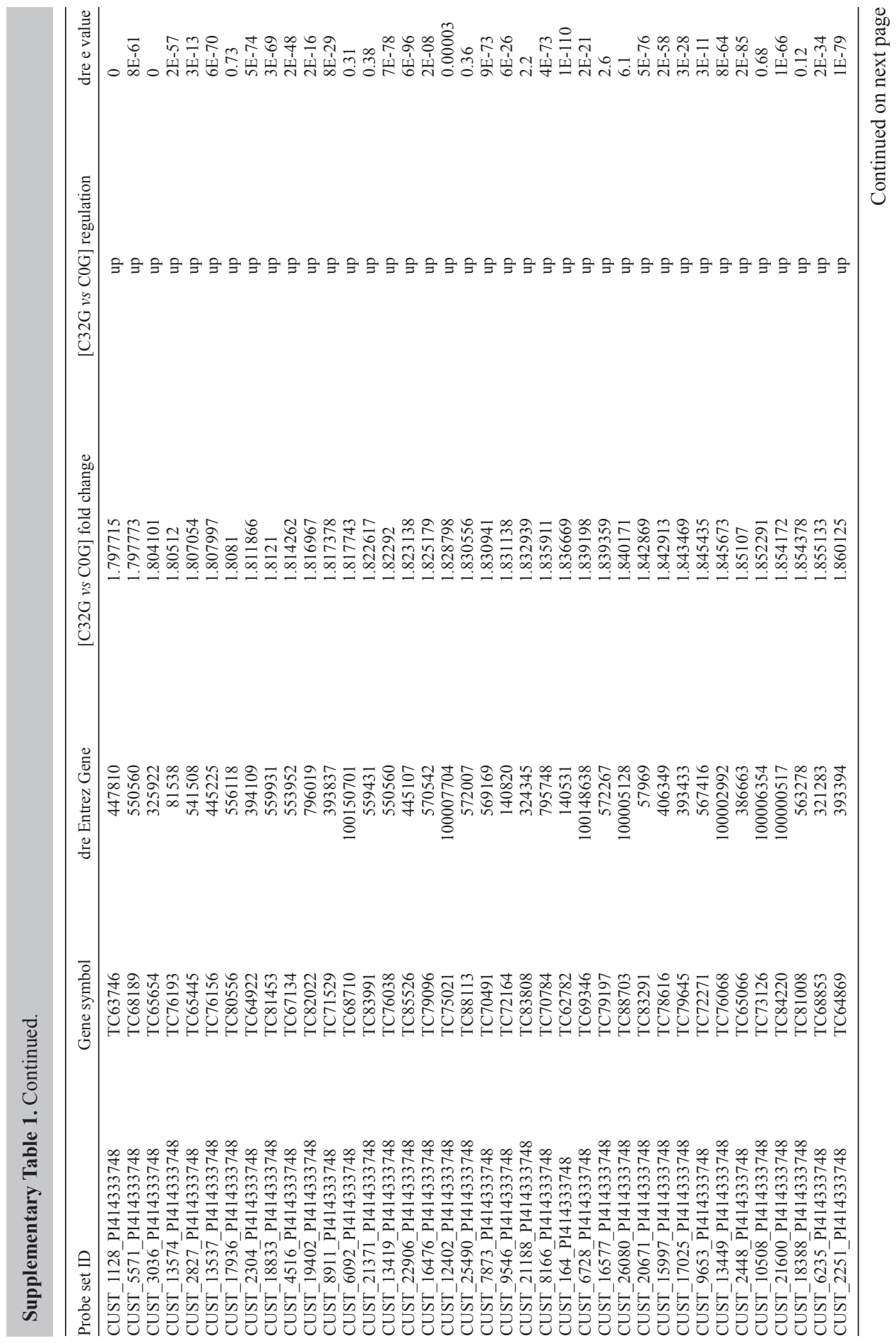




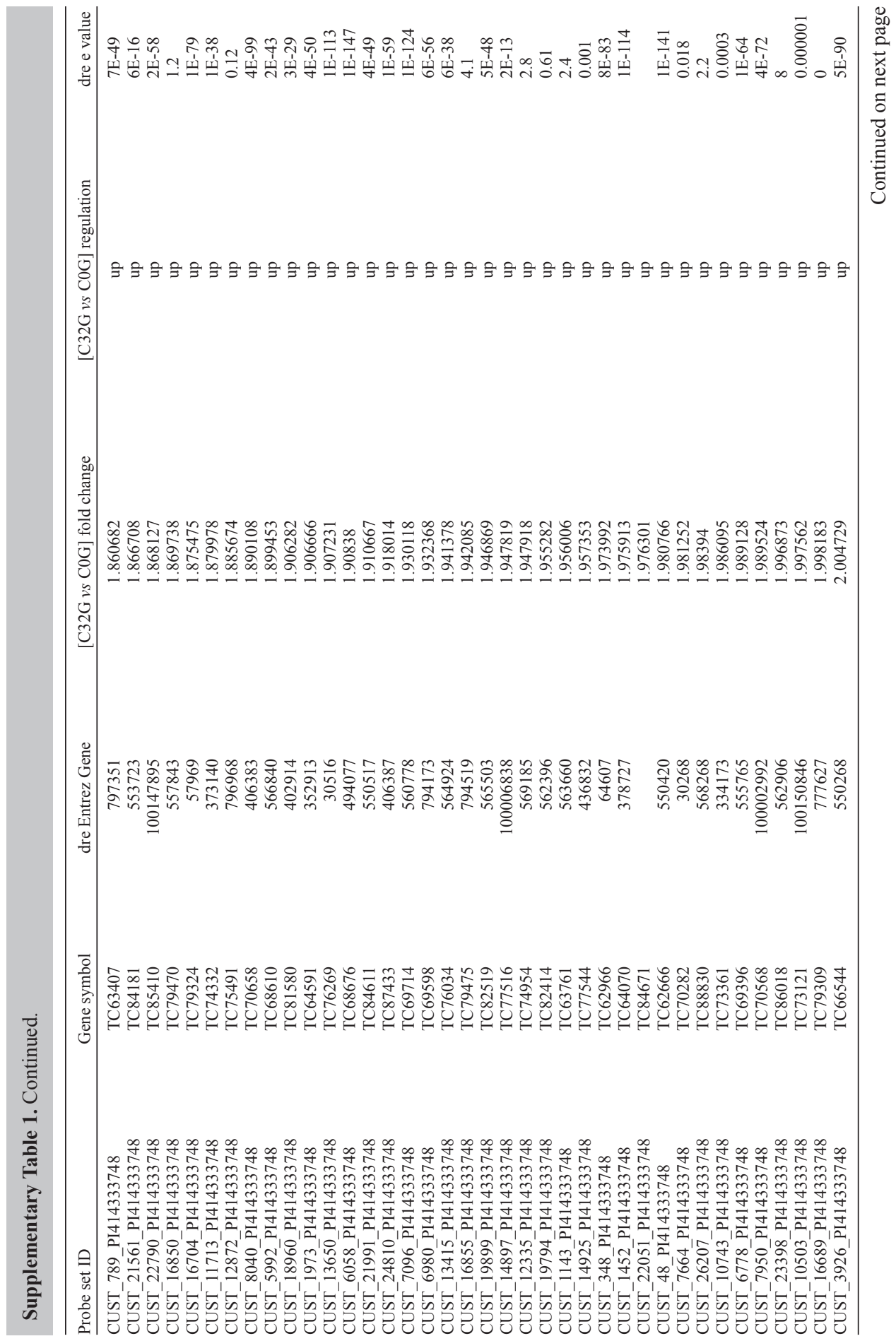




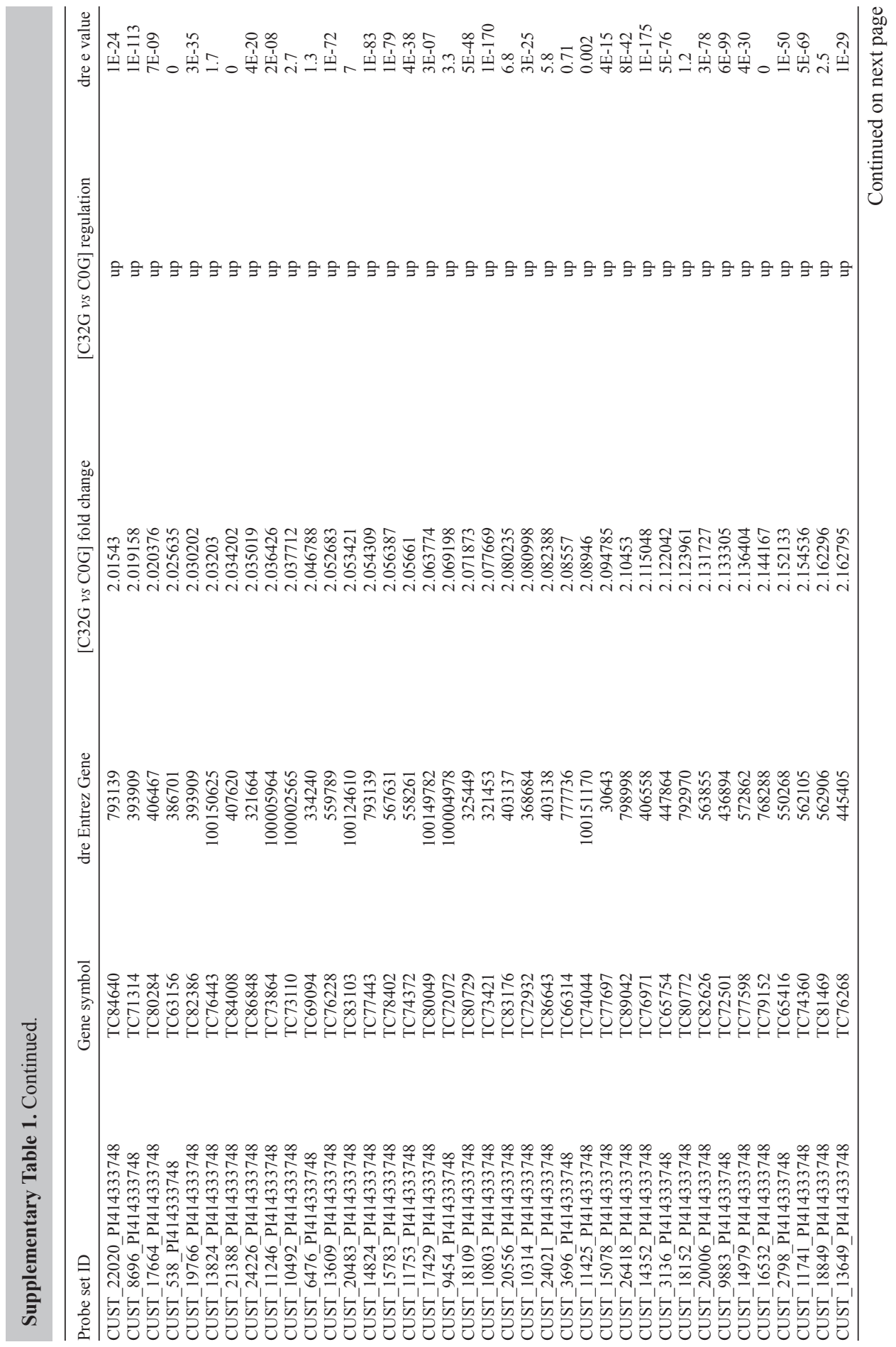




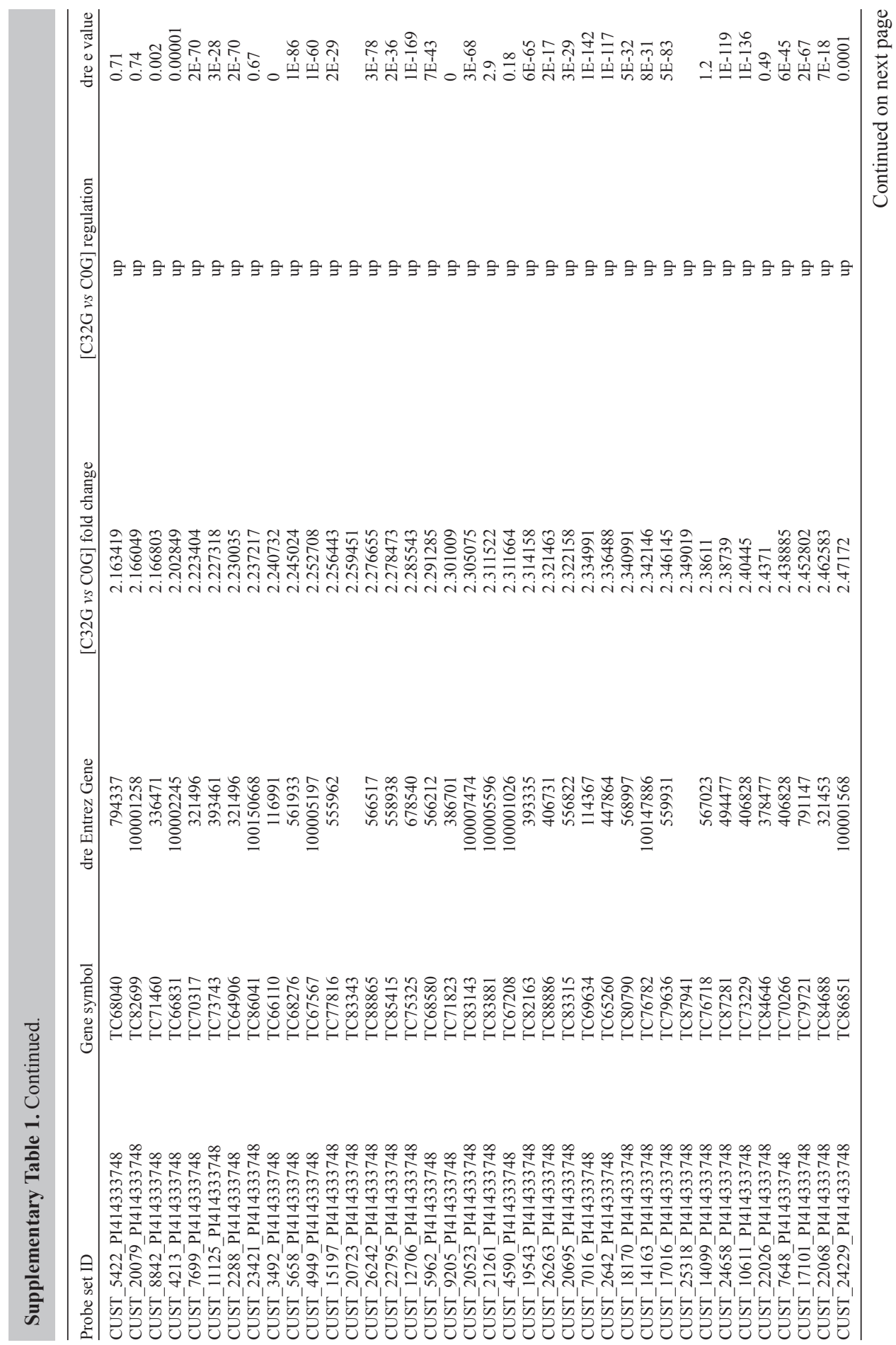




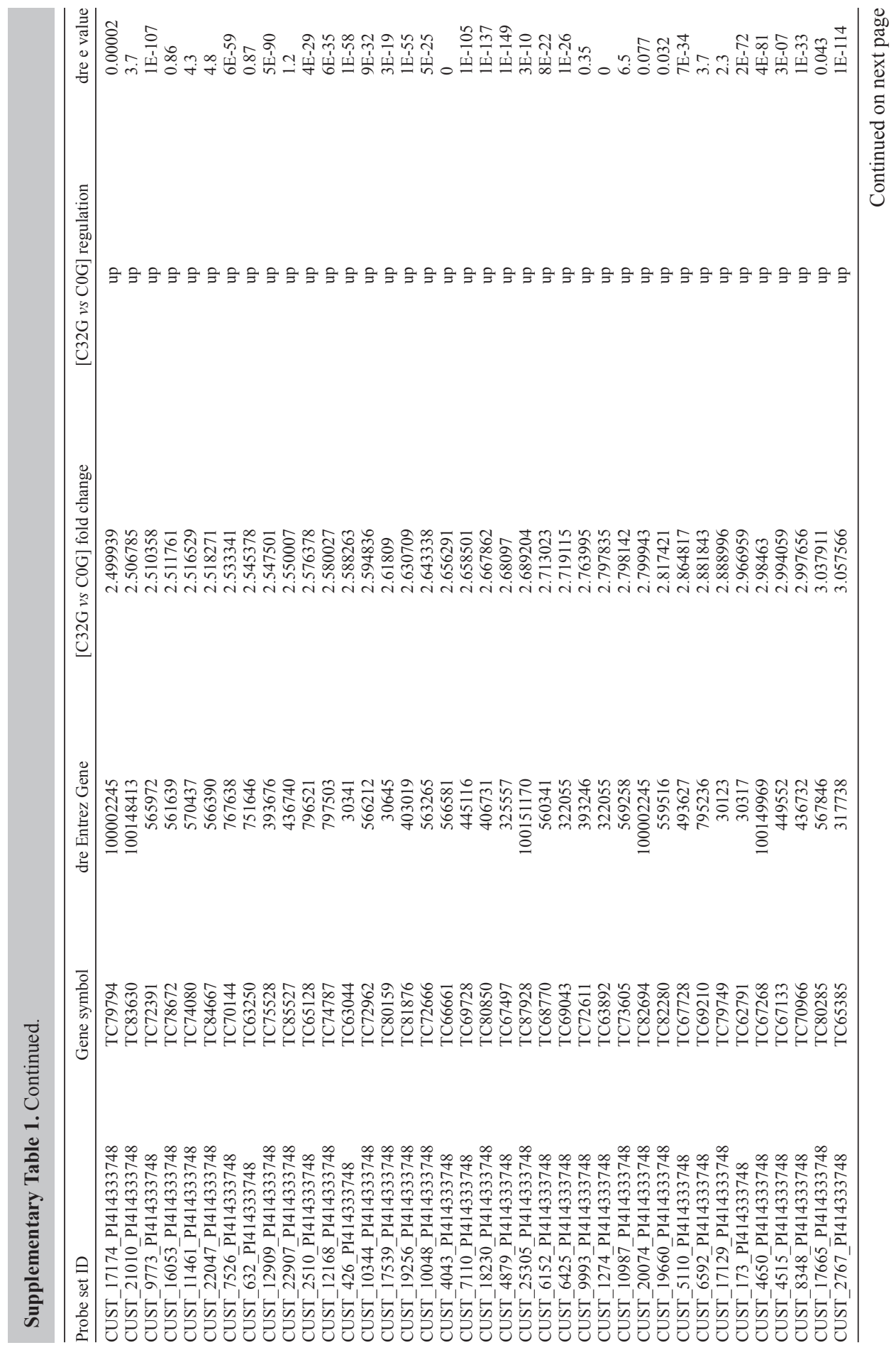




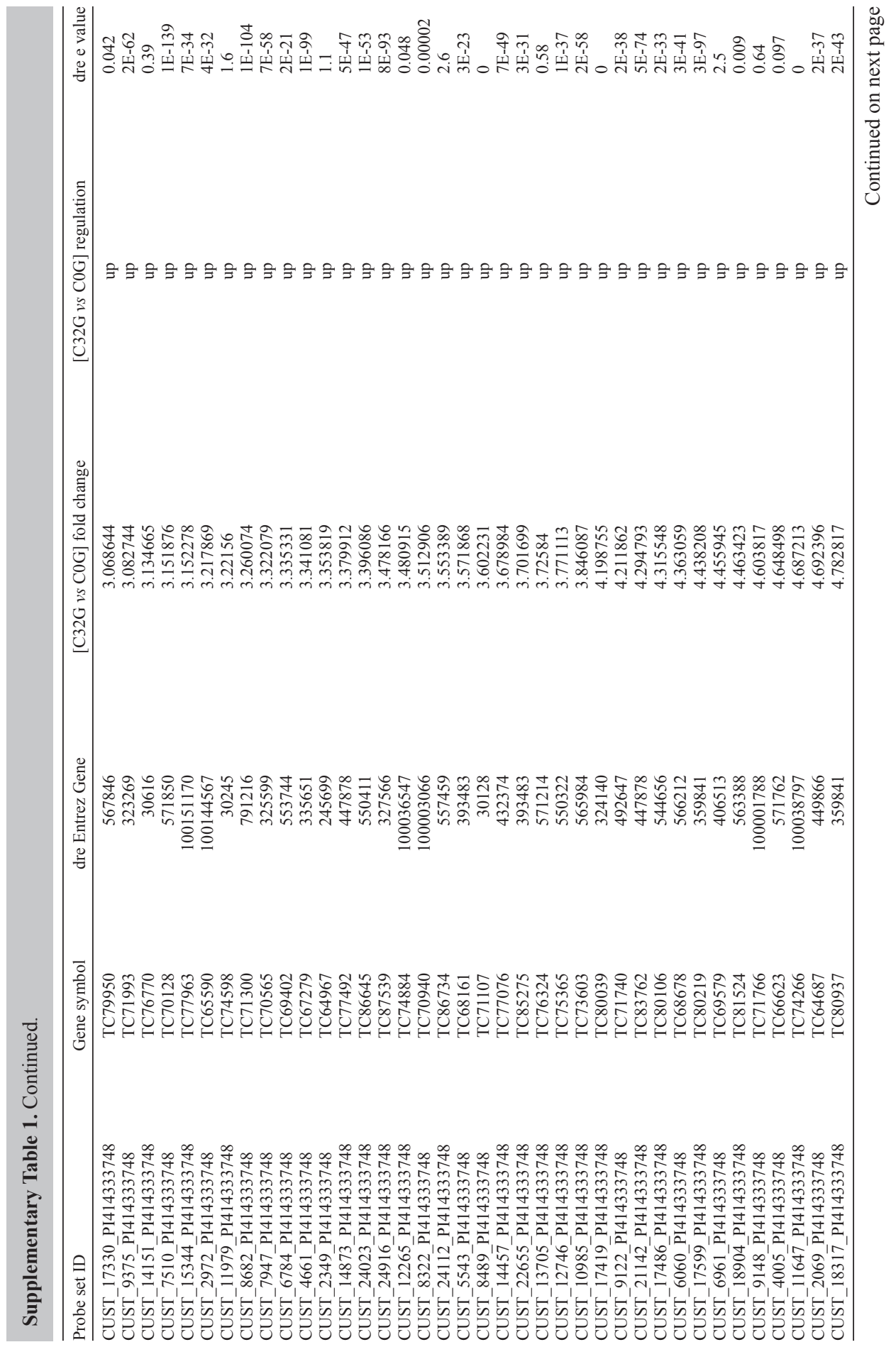




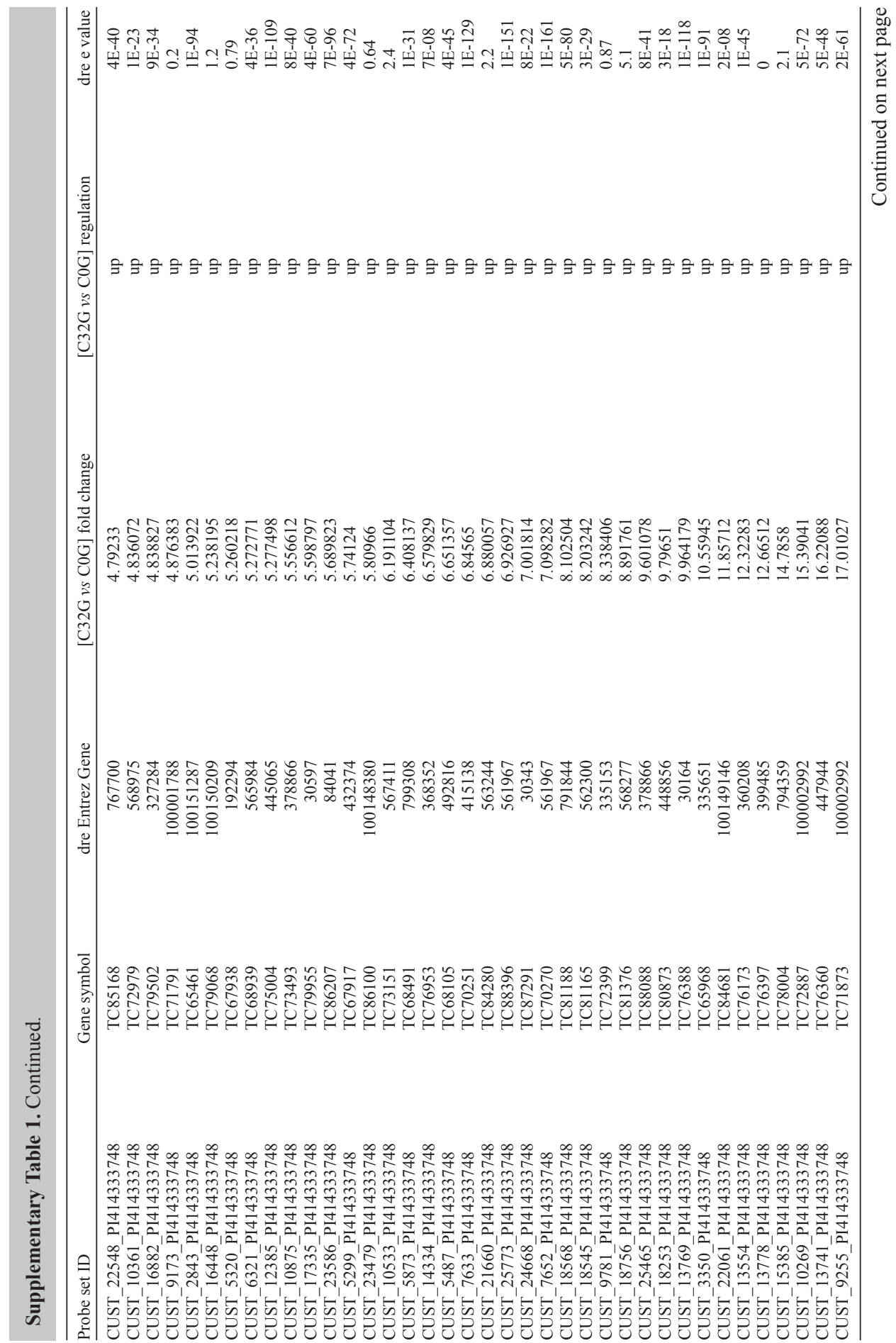




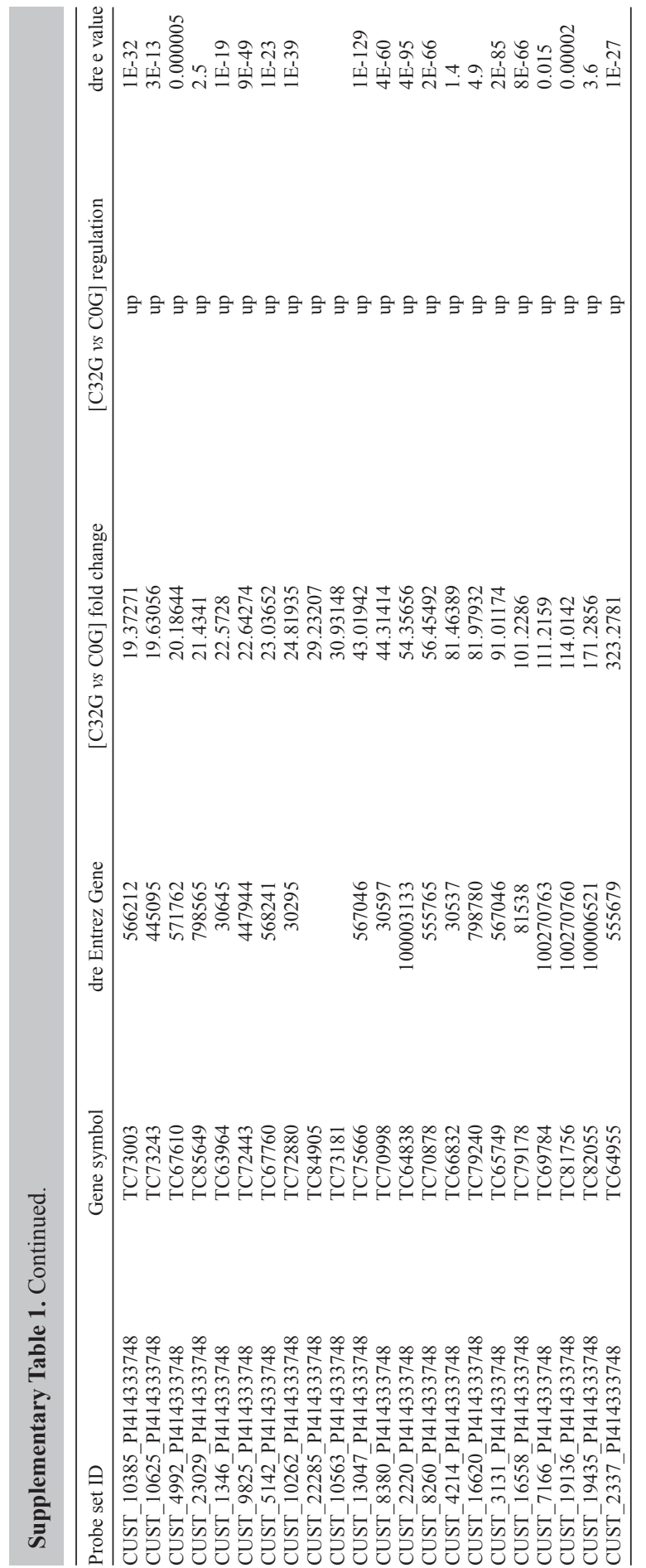




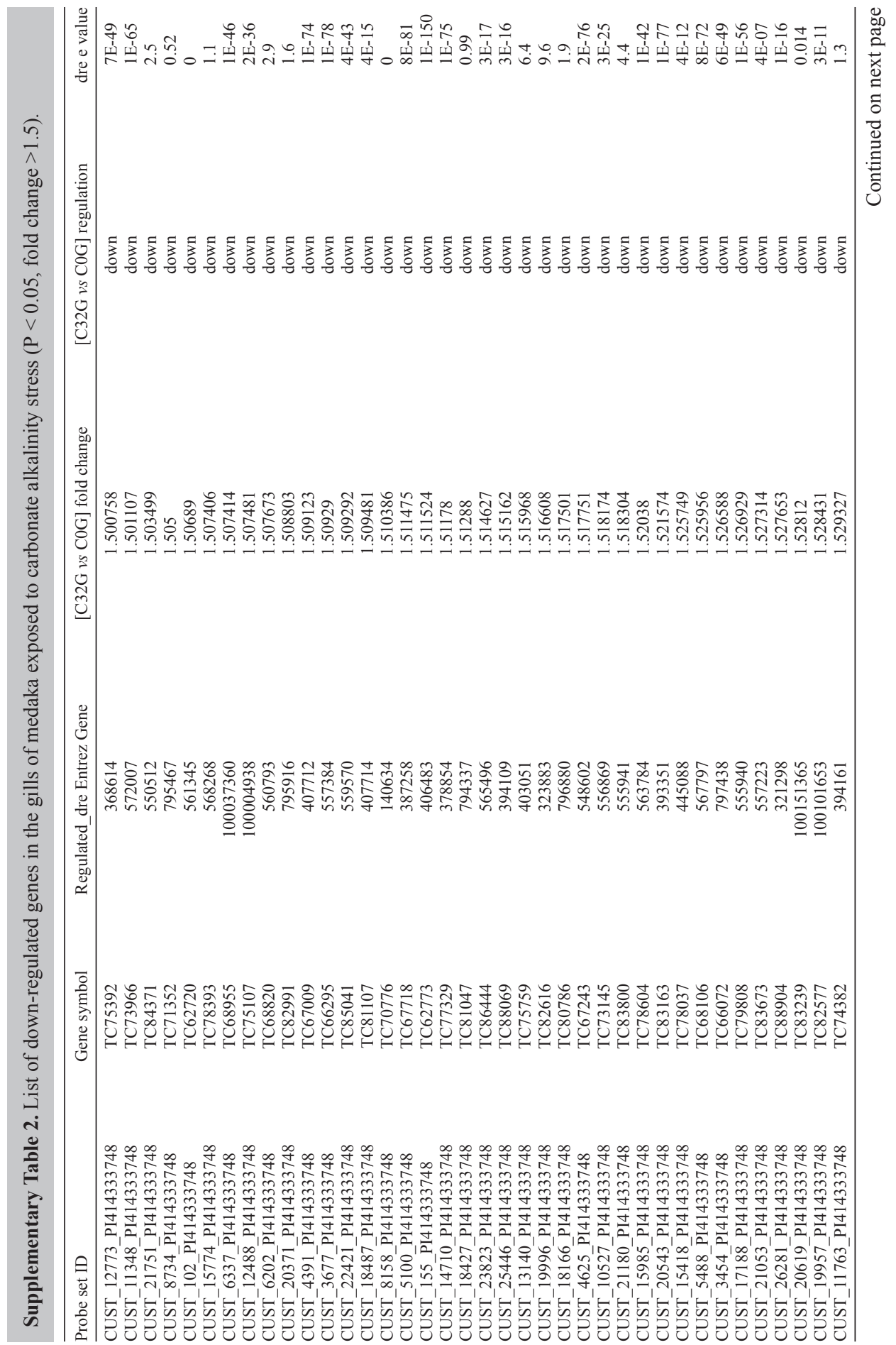




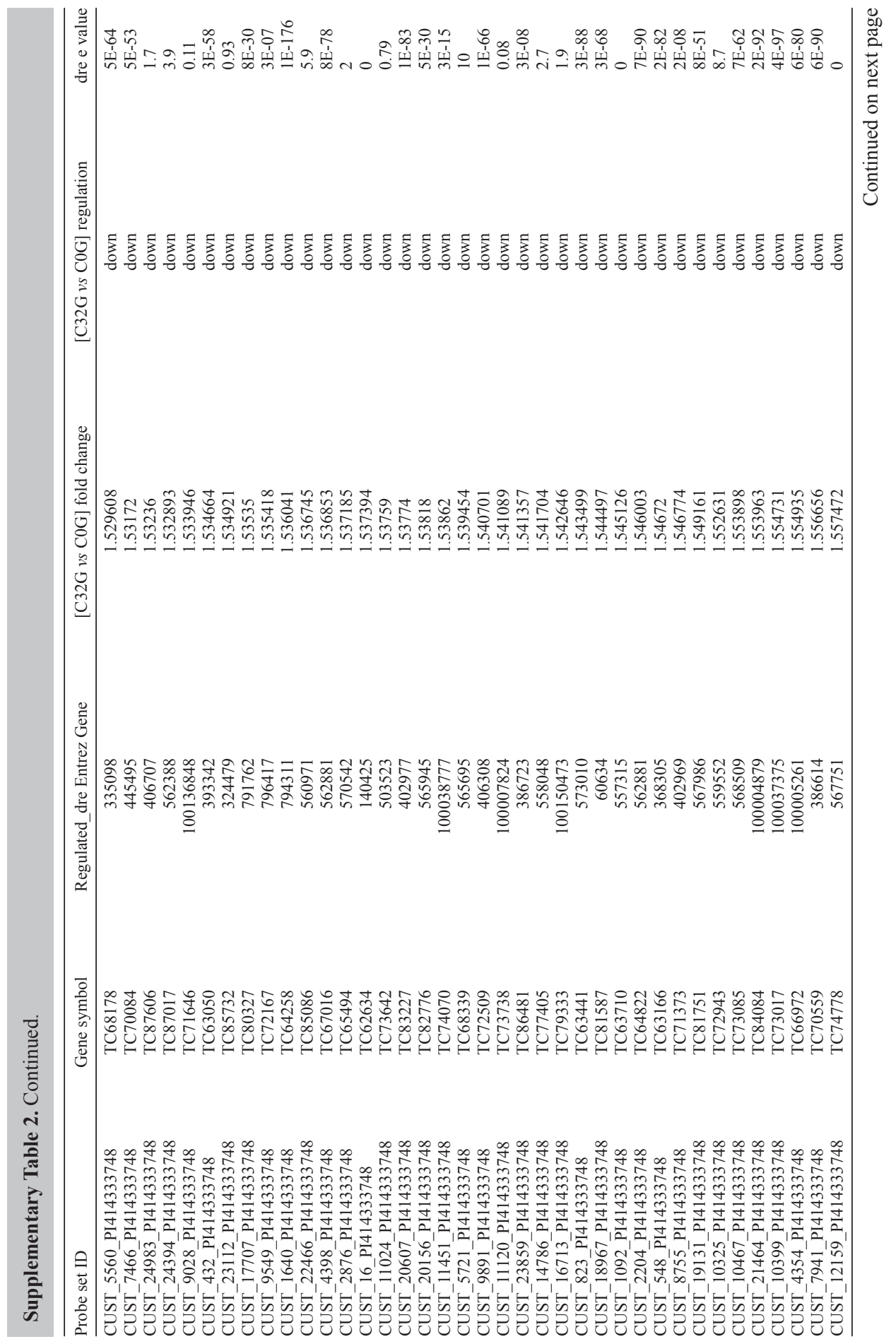




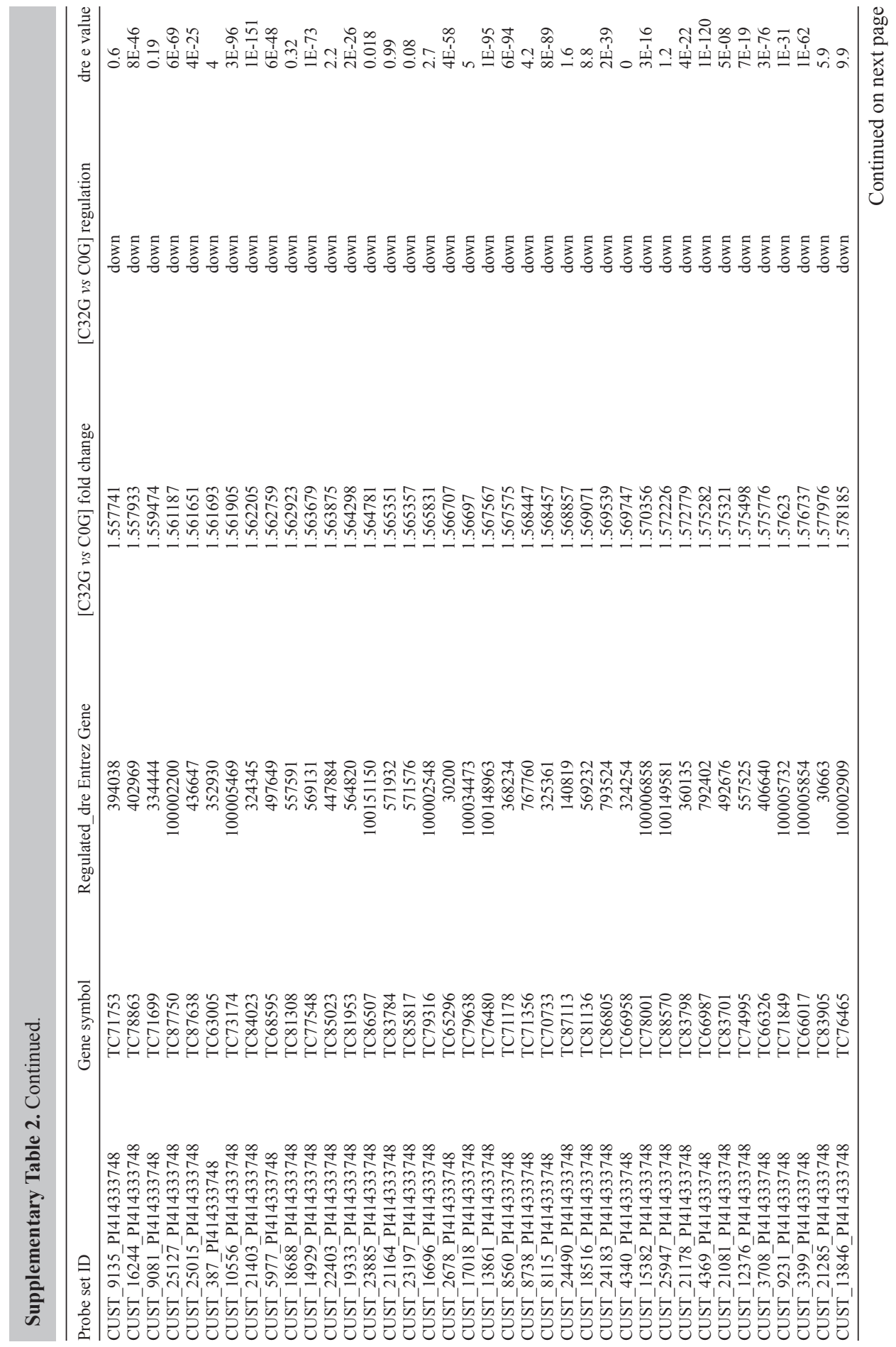




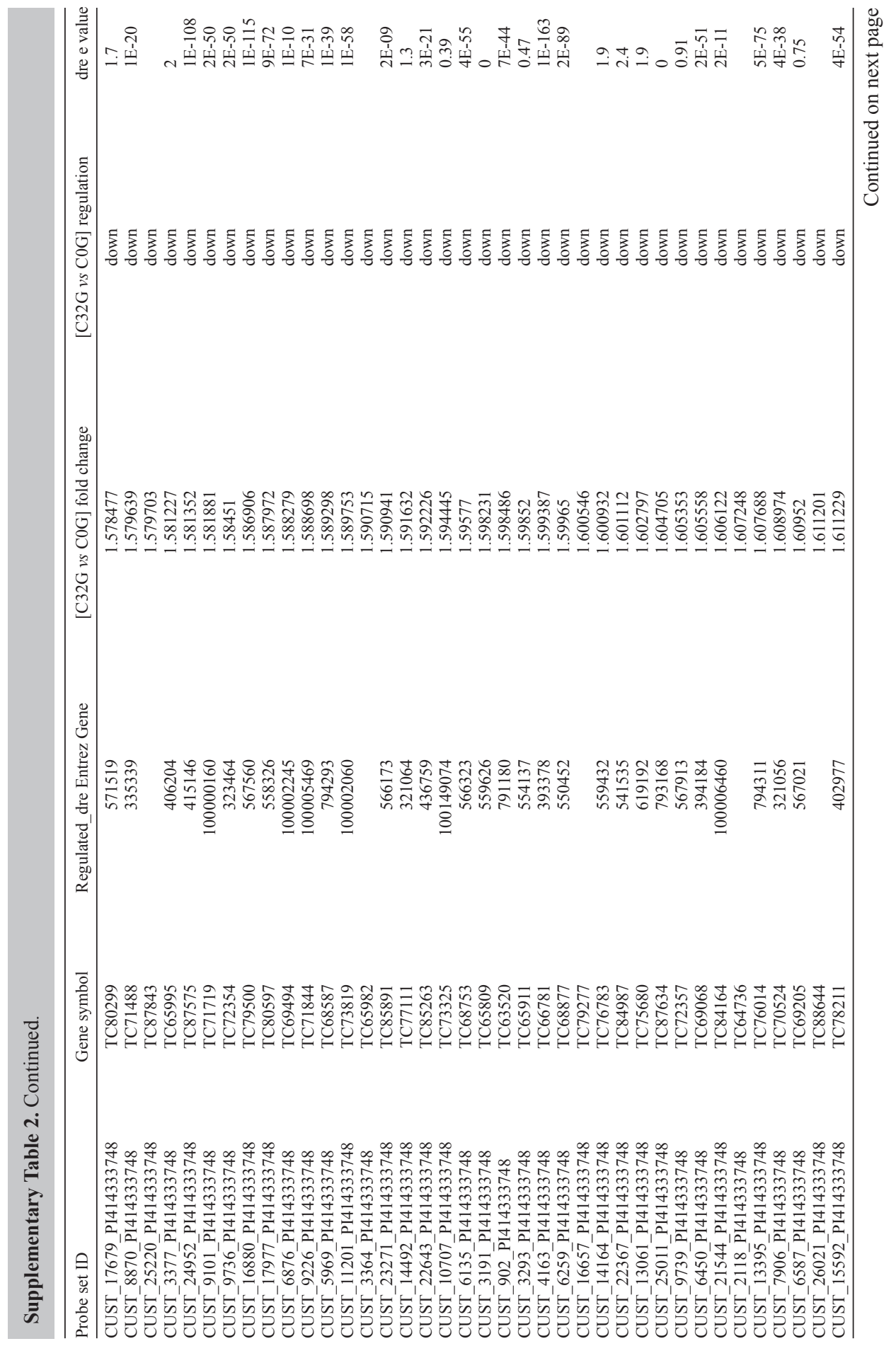




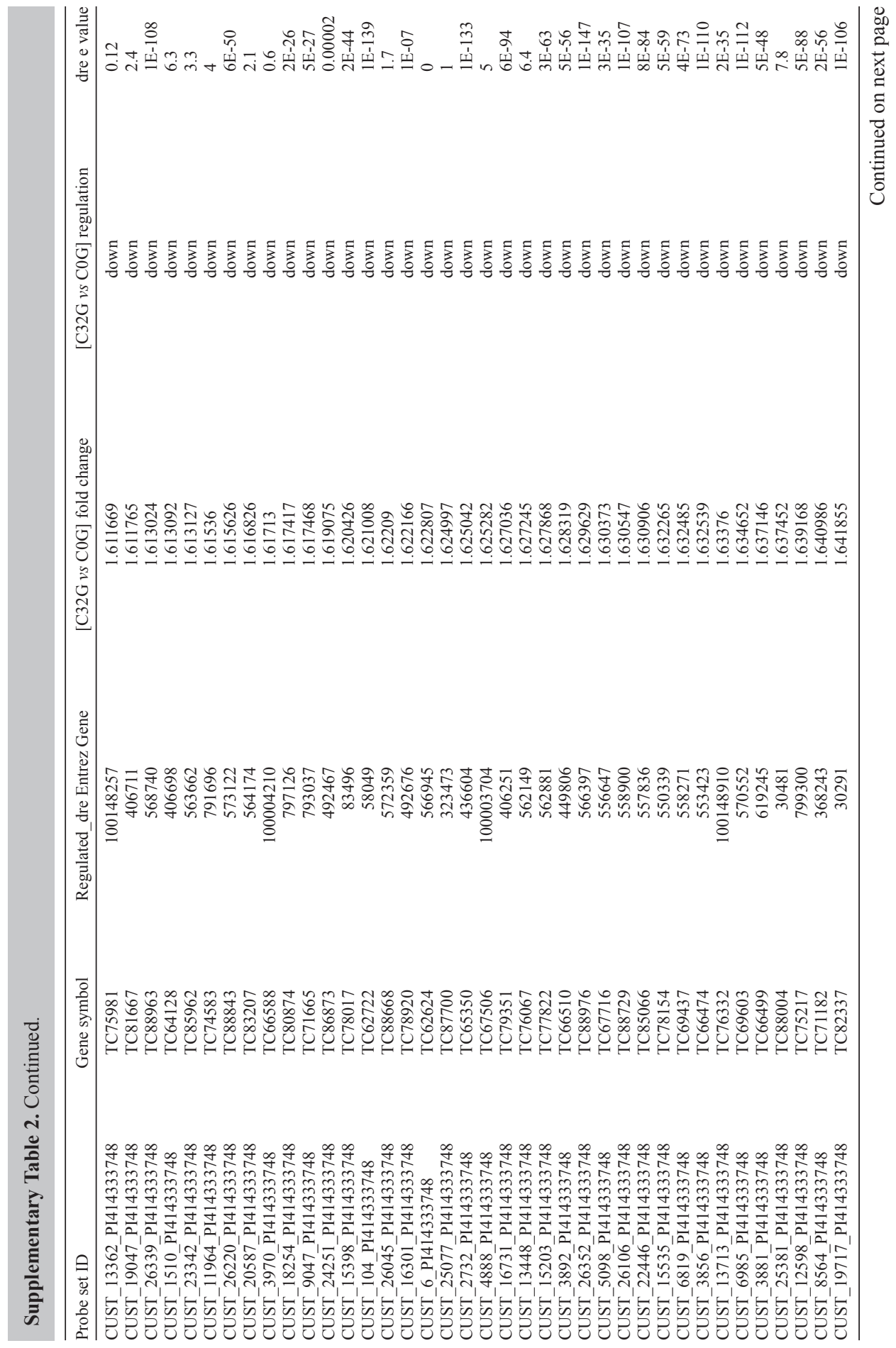




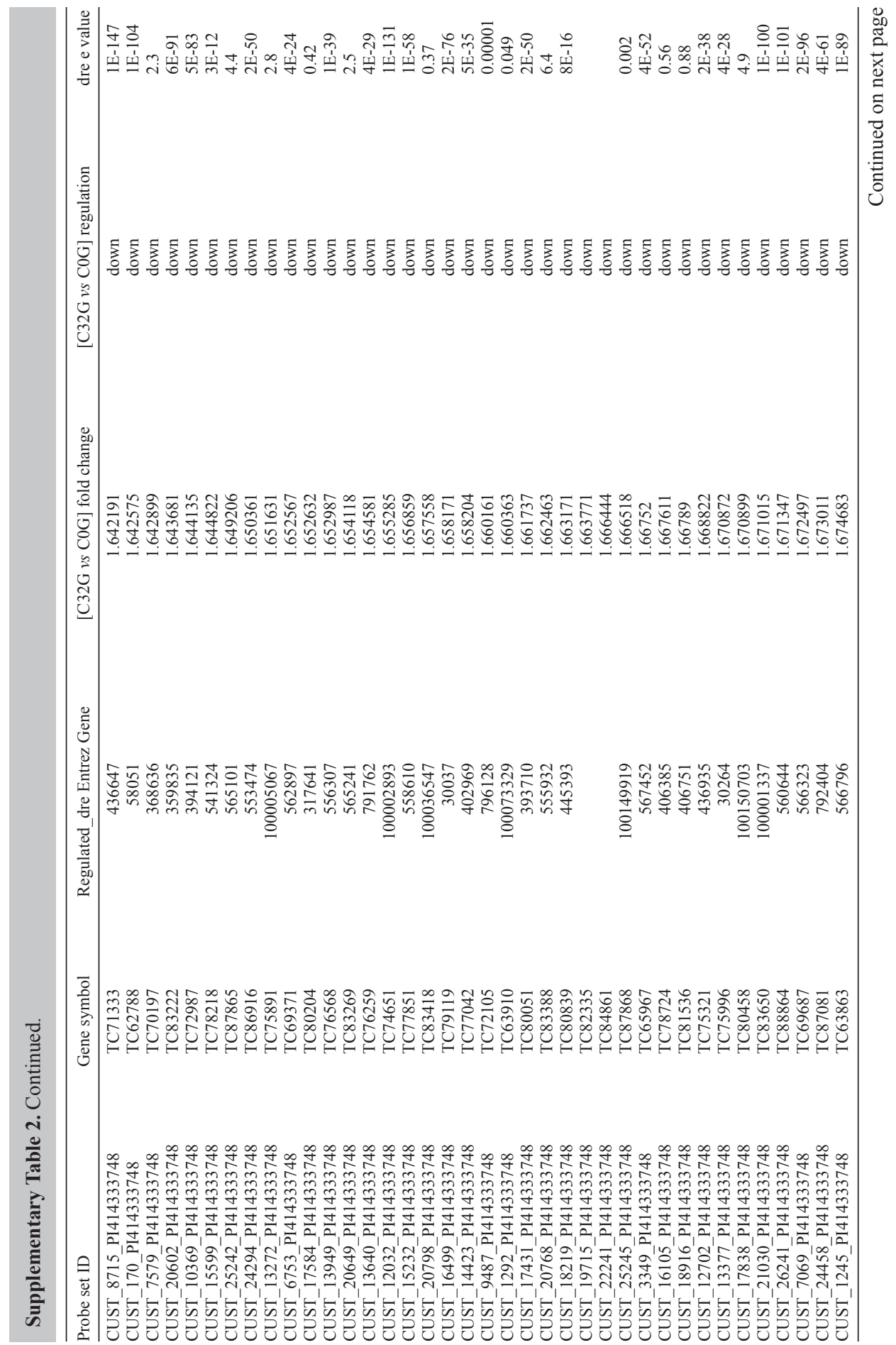




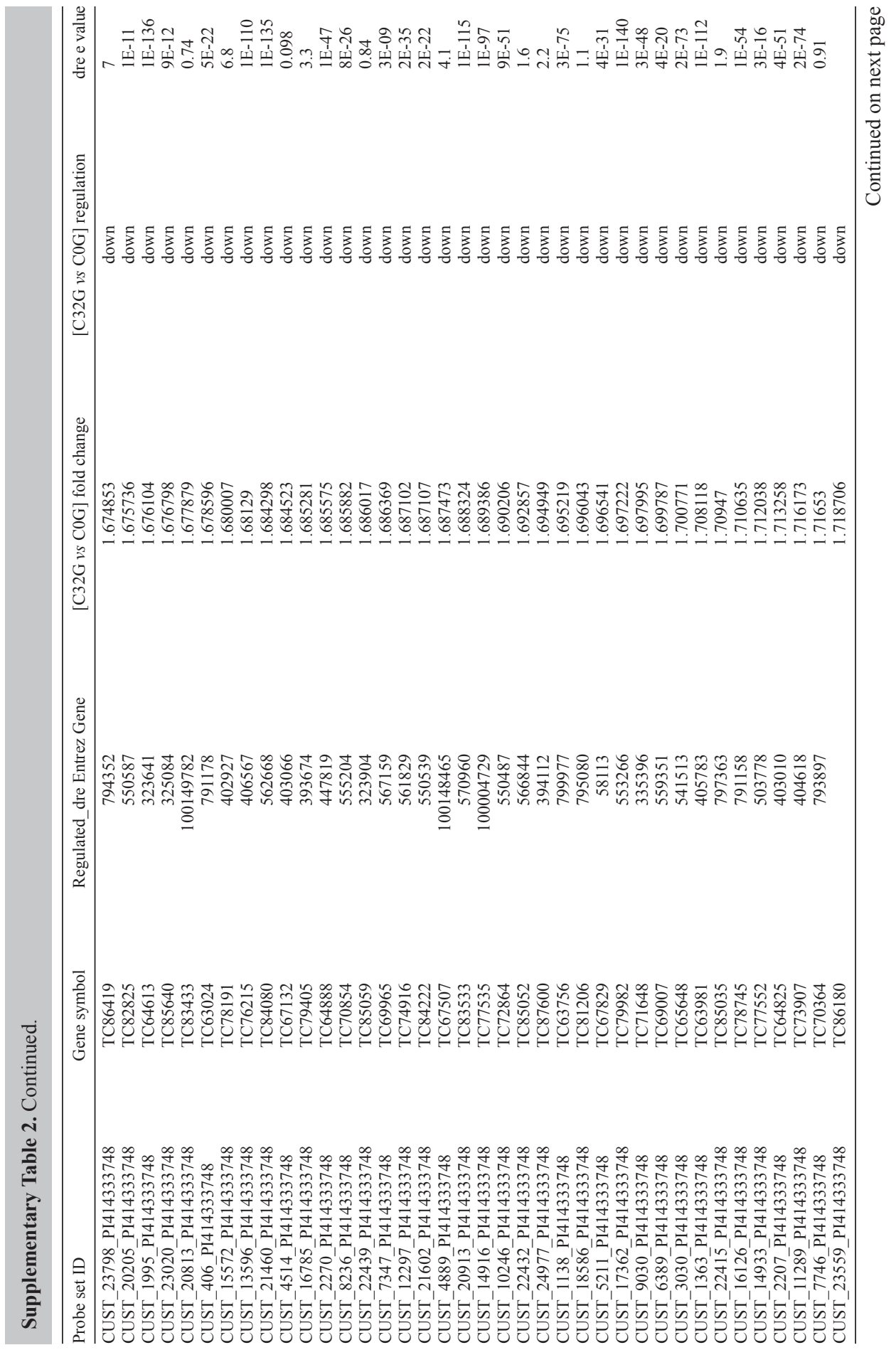




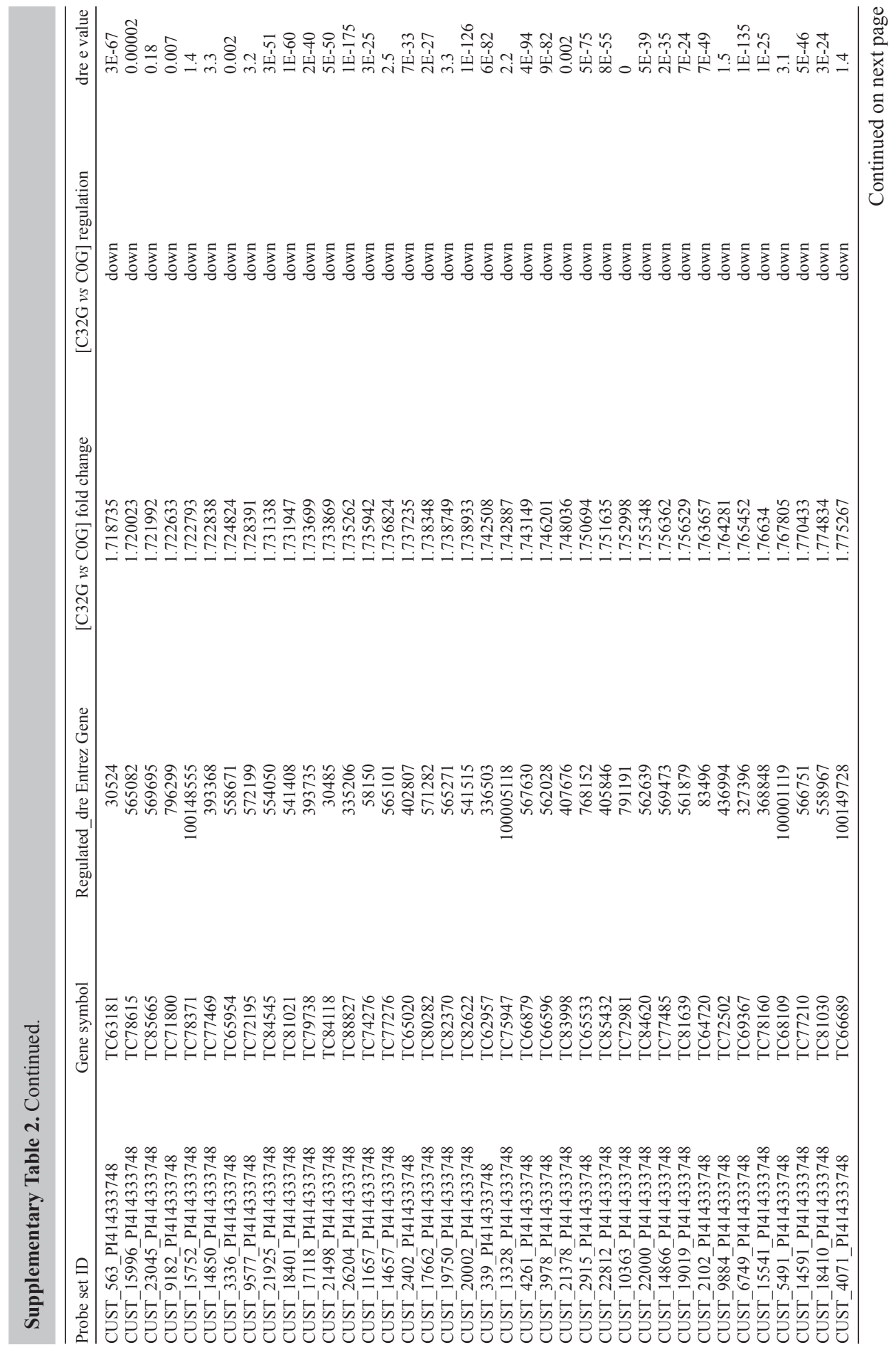




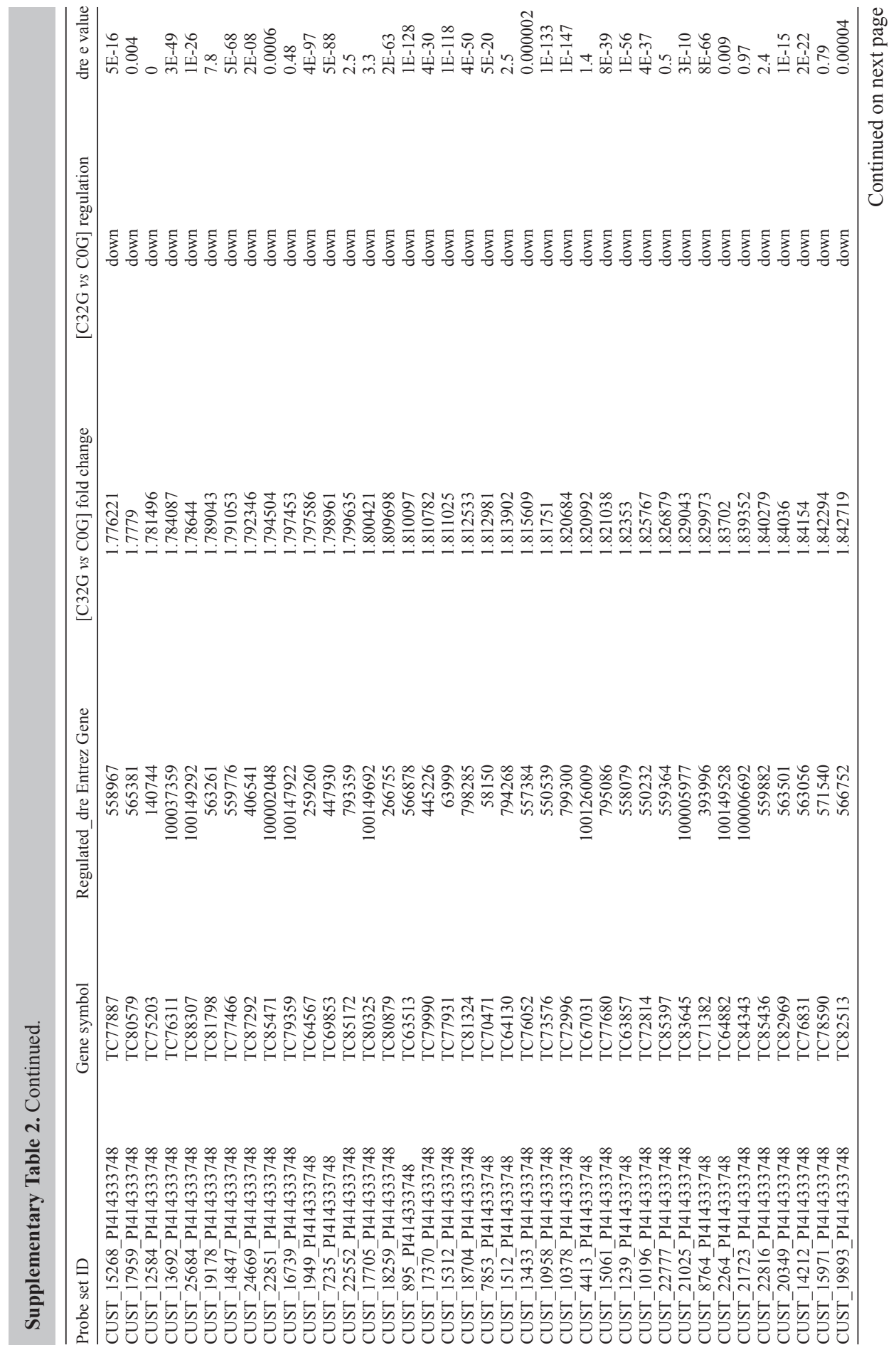




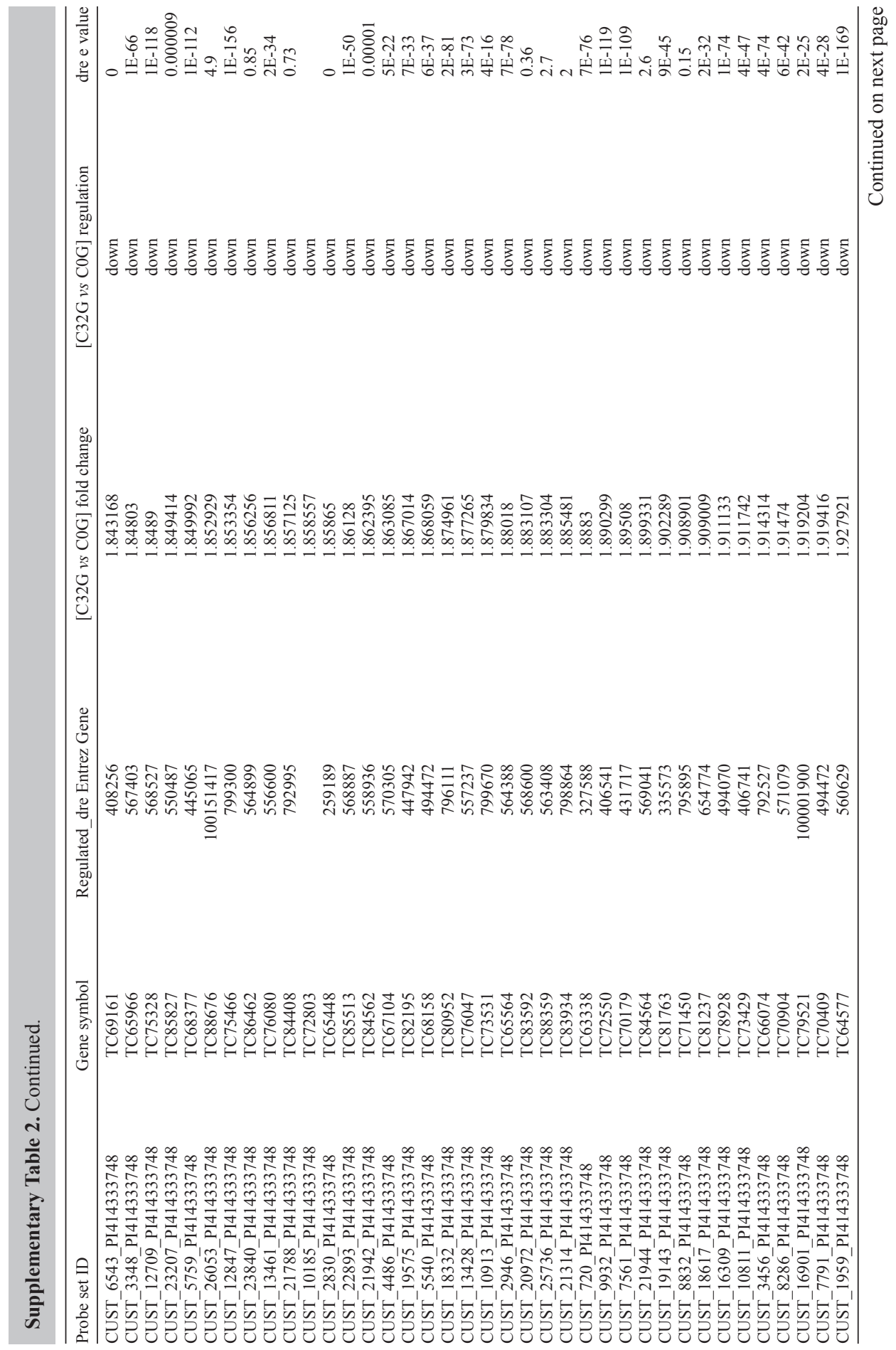




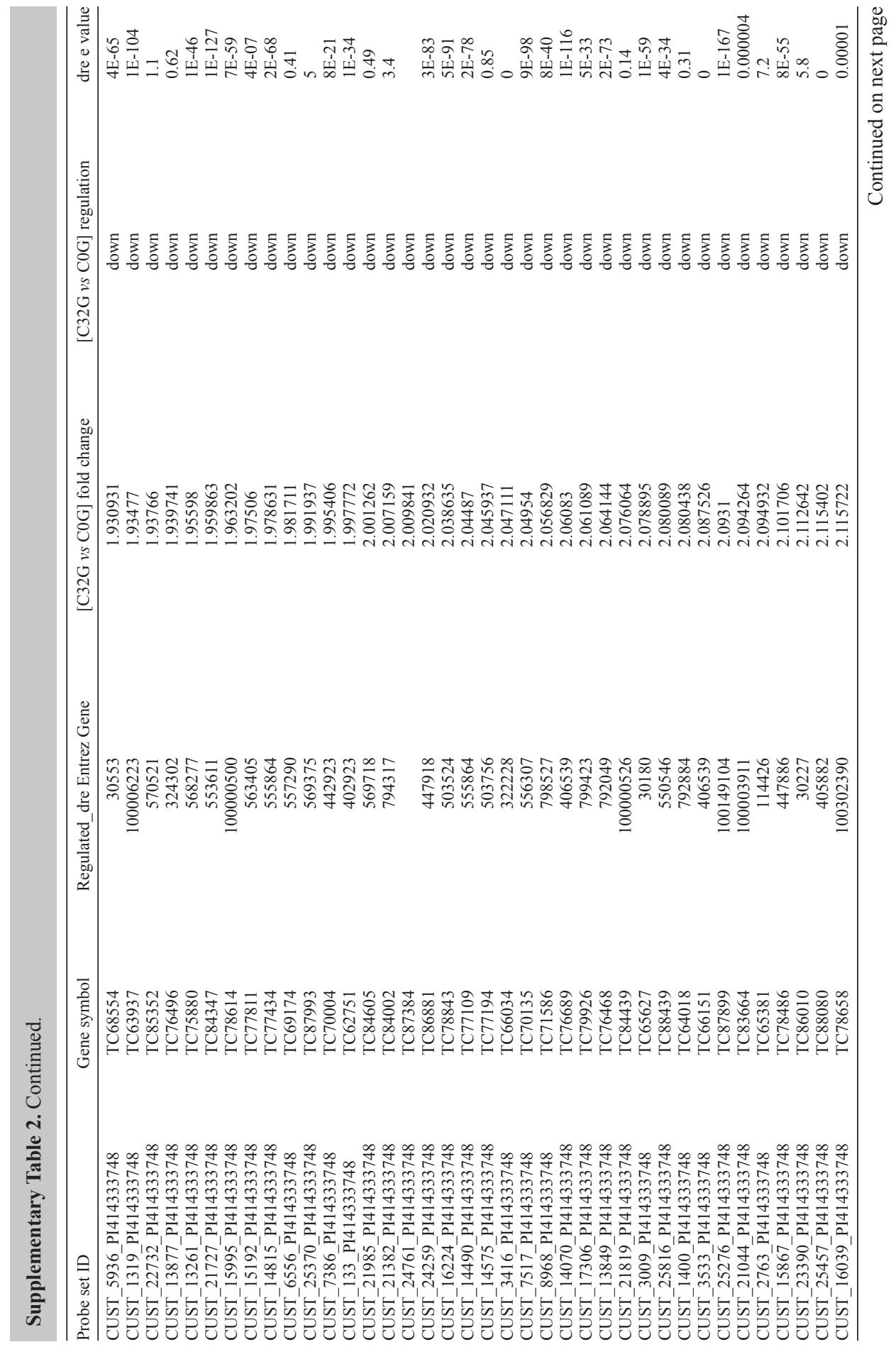




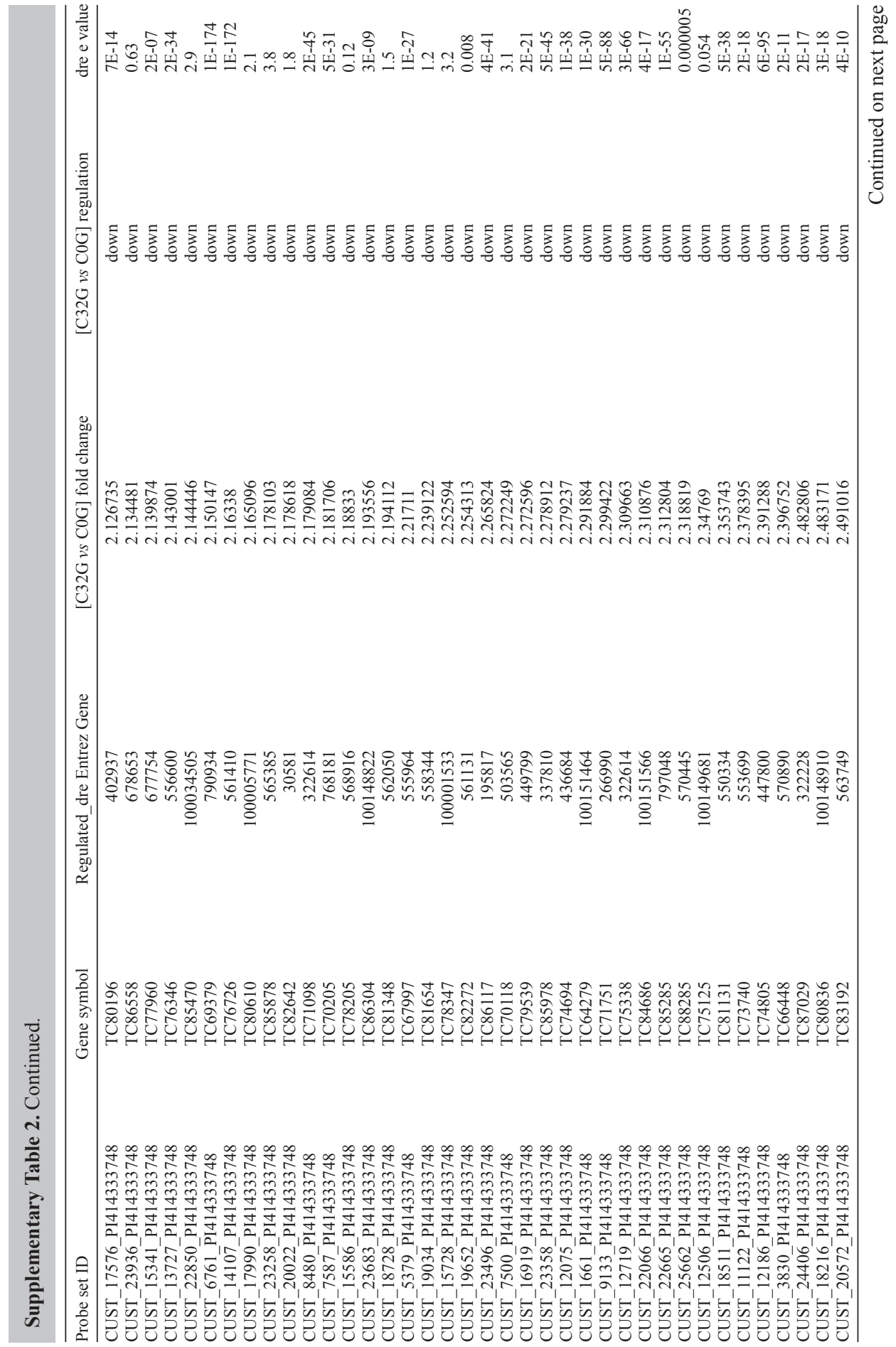




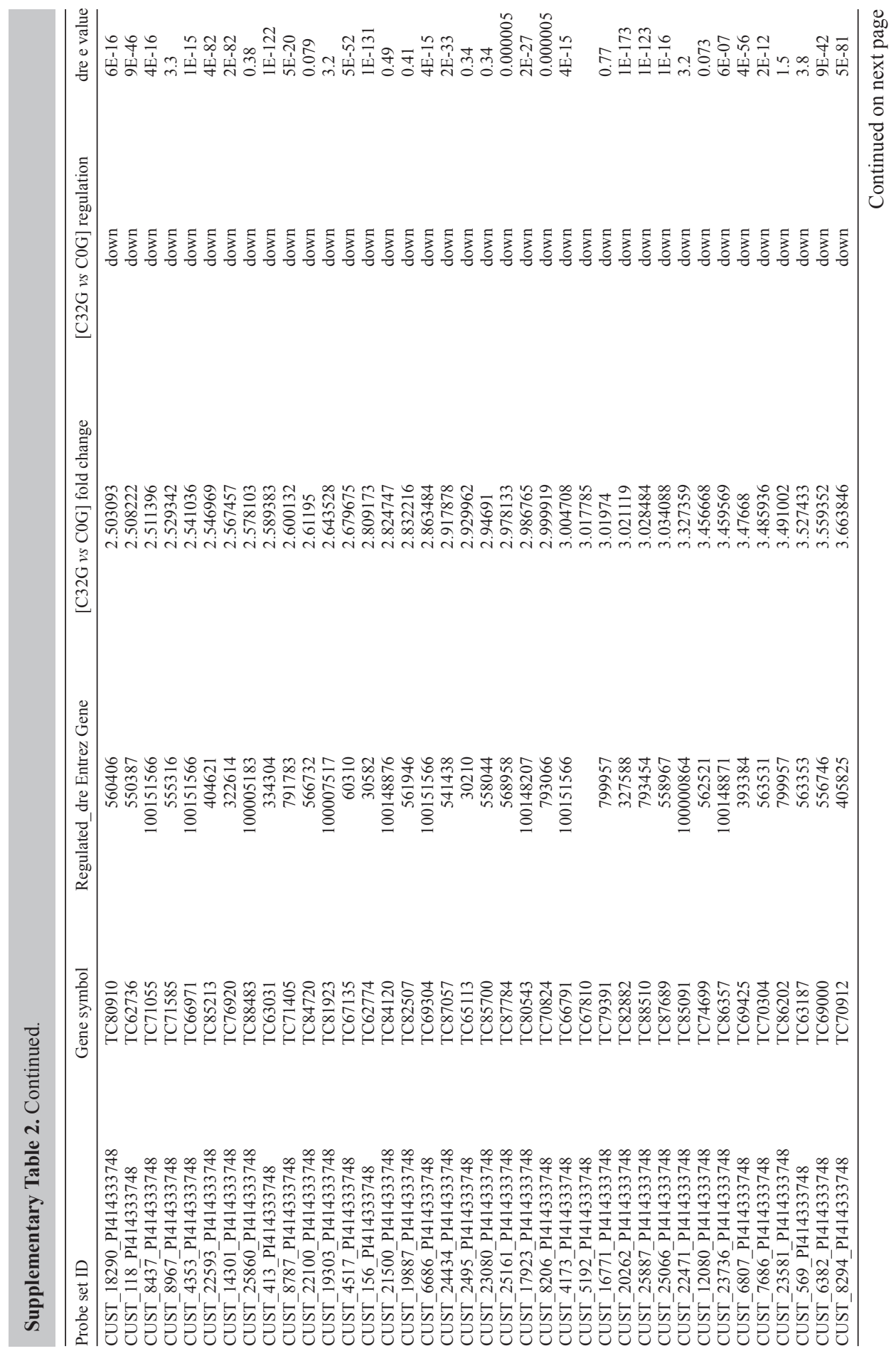




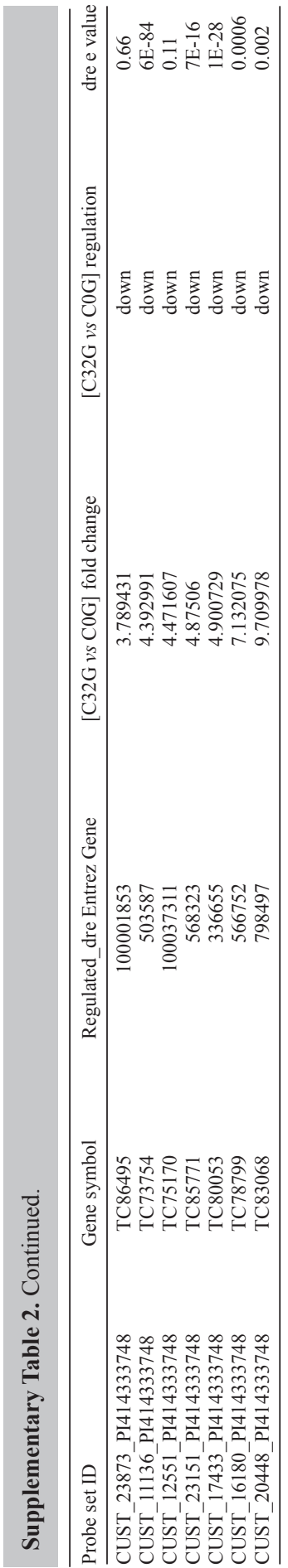

Genetics and Molecular Research 11 (3): 2200-2246 (2012) 